4

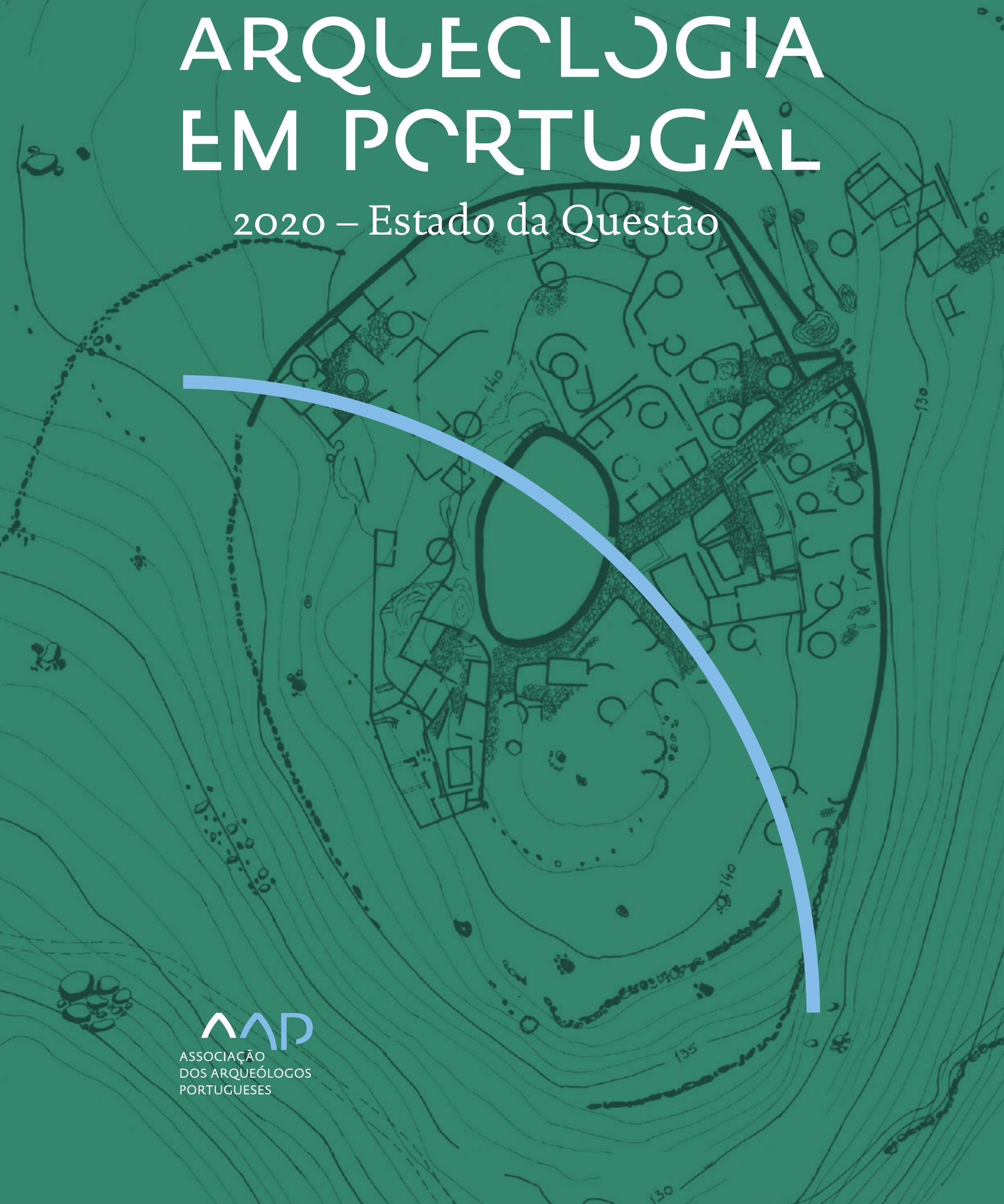


Coordenação editorial: José Morais Arnaud, César Neves e Andrea Martins Design gráfico: Flatland Design

AAP - ISBN: 978-972-9451-89-8

CITCEM - ISBN: 978-989-8970-25-1

Associação dos Arqueólogos Portugueses e CITCEM

Lisboa, 2020

O conteúdo dos artigos é da inteira responsabilidade dos autores. Sendo assim a Associação dos Arqueólogos Portugueses declina qualquer responsabilidade por eventuais equívocos ou questões de ordem ética e legal.

Desenho de capa:

Planta do castro de Monte Mozinho (Museu Municipal de Penafiel).

\section{$\hat{\wedge} \mathrm{P}$}

DOS ARQUEÓLOGOS PORTUGUESES

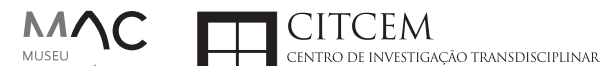
MUSEU
ARQUELLÓGICO
DO CARMO
U.PORTO

FLUP FACULDADE DE LETRAS
UNIVERSIDADE DO PORTO

Apoio

EC para a Ciência 


\section{Índice}

15 Prefácio

José Morais Arnaud

\section{Historiografia e Teoria}

17 Território, comunidade, memória e emoção: a contribuição da história da arqueologia (algumas primeiras e breves reflexões)

Ana Cristina Martins

25 Como descolonizar a arqueologia portuguesa?

Rui Gomes Coelho

41 Arqueologia e Modernidade: uma revisitação pessoal e breve de alguns aspetos da obra homónima de Julian Thomas de 2004

Vítor Oliveira Jorge

57 Dados para a História das Mulheres na Arqueologia portuguesa, dos finais do século XIX aos inícios do século XX: números, nomes e tabelas

Filipa Dimas / Mariana Diniz

73 Retractos da arqueologia portuguesa na imprensa: (in)visibilidades no feminino

Catarina Costeira / Elsa Luís

85 Arqueologia e Arqueólogos no Norte de Portugal Jacinta Bugalhão

101 Vieira Guimarães (1864-1939) e a arqueologia em Tomar: uma abordagem sobre o território e as gentes

João Amendoeira Peixoto / Ana Cristina Martins

115 Os memoráveis? A arqueologia algarvia na imprensa nacional e regional na presente centúria (2001-2019): características, visões do(s) passado(s) e a arqueologia

enquanto marca

Frederico Agosto / João Silva

129 A Evolução da Arqueologia Urbana e a Valorização Patrimonial no Barlavento Algarvio: Os casos de Portimão e Silves

Artur Mateus / Diogo Varandas / Rafael Boavida

\section{Gestão, Valorização e Salvaguarda do Património}

145 O Caderno Reivindicativo e as condições de trabalho em Arqueologia Miguel Rocha / Liliana Matias Carvalho / Regis Barbosa / Mauro Correia / Sara Simões / Jacinta Bugalhão / Sara Brito / Liliana Veríssimo Carvalho / Richard Peace / Pedro Peça / Cézer Santos

155 Os Estudos de Impacte Patrimonial como elemento para uma estratégia sustentável de minimização de impactes no âmbito de reconversões agrícolas Tiago do Pereiro

165 Salvaguarda de Património arqueológico em operações florestais: gestão e sensibilização Filipa Bragança / Gertrudes Zambujo / Sandra Lourenço / Belém Paiva / Carlos Banha / Frederico Tatá Regala / Helena Moura / Jacinta Bugalhão / João Marques / José Correia / Pedro Faria / Samuel Melro

179 Os valores do Património: uma investigação sobre os Sítios Pré-históricos de Arte Rupestre do Vale do Rio Côa e de Siega Verde José Paulo Francisco 
189 Conjugando recursos arqueológicos e naturais para potenciar as visitas ao Geoparque Litoral de Viana do Castelo (Noroeste de Portugal)

Hugo A. Sampaio / Ana M.S. Bettencourt / Susana Marinho / Ricardo Carvalhido

203 Áreas de Potencial Arqueológico na Região do Médio Tejo: Modelo Espacial Preditivo Rita Ferreira Anastácio / Ana Filipa Martins / Luiz Oosterbeek

223 Património Arqueológico e Gestão Territorial: O contributo da Arqueologia para a revisão do PDM de Avis

Ana Cristina Ribeiro

237 A coleção arqueológica do extinto Museu Municipal do Porto - Origens, Percursos e Estudos

Sónia Couto

251 Valpaços - uma nova carta arqueológica

Pedro Pereira / Maria de Fátima Casares Machado

263 Arqueologia na Cidade de Peniche

Adriano Constantino / Luís Rendeiro

273 Arqueologia Urbana: a cidade de Lagos como caso de Estudo Cátia Neto

285 Estratégias de promoção do património cultural subaquático nos Açores. O caso da ilha do Faial

José Luís Neto / José Bettencourt / Luís Borges / Pedro Parreira

297 Carta Arqueológica da Cidade Velha: Uma primeira abordagem

Jaylson Monteiro / Nireide Tavares / Sara da Veiga / Claudino Ramos / Edson Brito /

Carlos Carvalho / Francisco Moreira / Adalberto Tavares

311 Antropologia Virtual: novas metodologias para a análise morfológica e funcional Ricardo Miguel Godinho / Célia Gonçalves

\section{Didáctica da Arqueologia}

327 Como os projetos de Arqueologia podem contribuir para uma comunidade culturalmente mais consciente Alexandra Figueiredo / Claúdio Monteiro / Adolfo Silveira / Ricardo Lopes

337 Educação Patrimonial - Um cidadão esclarecido é um cidadão ativo! Ana Paula Almeida

351 A aproximação da Arqueologia à sala de aula: um caso de estudo no $3^{\circ}$ ciclo do Ensino Básico Luís Serrão Gil

363 Arqueologia 3.o - Pensar e comunicar a Arqueologia para um futuro sustentável Mónica Rolo

377 “Conversa de Arqueólogos" - Divulgar a Arqueologia em tempos de Pandemia Diogo Teixeira Dias

389 Escola Profissional de Arqueologia: desafios e oportunidades Susana Nunes / Dulcineia Pinto / Júlia Silva / Ana Mascarenhas

399 Os Museus de Arqueologia e os Jovens: a oferta educativa para o público adolescente Beatriz Correia Barata / Leonor Medeiros

411 O museu universitário como mediador entre a ciência e a sociedade: o exemplo da secção de arqueologia no Museu de História Natural e da Ciência da Universidade do Porto (MHNC-UP)

Rita Gaspar 
421 Museu de Lanifícios: Real Fábrica de Panos. Atividades no âmbito da Arqueologia Beatriz Correia Barata / Rita Salvado

427 Arqueologia Pública e o caso da localidade da Mata (Torres Novas) Cláudia Manso / Ana Rita Ferreira / Cristiana Ferreira / Vanessa Cardoso Antunes

431 Do sítio arqueológico ao museu: um percurso (também) didático Lídia Fernandes

447 Estão todos convidados para a Festa! E para dançar também... O projecto do Serviço Educativo do Museu Arqueológico do Carmo na $5^{\underline{a}}$ Edição da Festa da Arqueologia Rita Pires dos Santos

459 O “Clã de Carenque”, um projeto didático de arqueologia Eduardo Gonzalez Rocha

469 Mediação cultural: peixe que puxa carroça nas Ruínas Romanas de Troia Inês Vaz Pinto / Ana Patrícia Magalhães / Patrícia Brum / Filipa Santos

481 Didática Arqueológica, experiências do Projeto Mértola Vila Museu Maria de Fátima Palma / Clara Rodrigues / Susana Gómez / Lígia Rafael

\section{Arte Rupestre}

497 Os inventários de arte rupestre em Portugal Mila Simões de Abreu

513 O projeto FIRST-ART - conservação, documentação e gestão das primeiras manifestações de arte rupestre no Sudoeste da Península Ibérica: as grutas do Escoural e Maltravieso Sara Garcês / Hipólito Collado / José Julio García Arranz / Luiz Oosterbeek / António Carlos Silva / Pierluigi Rosina / Hugo Gomes / Anabela Borralheiro Pereira / George Nash / Esmeralda Gomes / Nelson Almeida / Carlos Carpetudo

523 Trabalhos de documentação de arte paleolítica realizados no âmbito do projeto PalæoCôa André Tomás Santos / António Fernando Barbosa / Luís Luís / Marcelo Silvestre / Thierry Aubry

537 Imagens fantasmagóricas, silhuetas elusivas: as figuras humanas na arte do Paleolítico Superior da região do Côa Mário Reis

$55^{1}$ Os motivos zoomórficos representados nas placas de tear de Vila Nova de São Pedro (Azambuja, Portugal) Andrea Martins / César Neves / José M. Arnaud / Mariana Diniz

571 Arte Rupestre do Monte de Góios (Lanhelas, Caminha). Síntese dos resultados dos trabalhos efectuados em 2007-2009 Mário Varela Gomes

599 Gravuras rupestres de barquiformes no Monte de S. Romão, Guimarães, Noroeste de Portugal Daniela Cardoso

613 Círculos segmentados gravados na Bacia do Rio Lima (Noroeste de Portugal): contributos para o seu estudo Diogo Marinho / Ana M.S. Bettencourt / Hugo Aluai Sampaio

631 Equídeos gravados no curso inferior do Rio Mouro, Monção (NW Portugal). Análise preliminar Coutinho, L.M. / Bettencourt, A.M.S / Sampaio, Hugo A.S

645 Paletas na Arte Rupestre do Noroeste de Portugal. Inventário preliminar Bruna Sousa Afonso / Ana M. S. Bettencourt / Hugo A. Sampaio 


\section{Pré-História}

661 O projeto Miño/Minho: balanço de quatro anos de trabalhos arqueológicos Sérgio Monteiro-Rodrigues / João Pedro Cunha-Ribeiro / Eduardo Méndez-Quintas / Carlos Ferreira / Pedro Xavier / José Meireles / Alberto Gomes / Manuel Santonja / Alfredo Pérez-González

677 A ocupação paleolítica da margem esquerda do Baixo Minho: a indústria lítica do sítio de Pedreiras 2 (Monção, Portugal) e a sua integração no contexto regional Carlos Ferreira / João Pedro Cunha-Ribeiro / Sérgio Monteiro-Rodrigues / Eduardo Méndez-Quintas / Pedro Xavier / José Meireles / Alberto Gomes / Manuel Santonja / Alfredo Pérez-González

693 O sítio acheulense do Plistocénico médio da Gruta da Aroeira Joan Daura / Montserrat Sanz / Filipa Rodrigues / Pedro Souto / João Zilhão

703 As sociedades neandertais no Barlavento algarvio: modelos preditivos com recurso aos SIG

Daniela Maio

715 A utilização de quartzo durante o Paleolítico Superior no território dos vales dos rios Vouga e Côa

Cristina Gameiro / Thierry Aubry / Bárbara Costa / Sérgio Gomes / Luís Luís / Carmen Manzano / André Tomás Santos

733 Uma perspetiva diacrónica da ocupação do concheiro do Cabeço da Amoreira (Muge, Portugal) a partir da tecnologia lítica Joana Belmiro / João Cascalheira / Célia Gonçalves

745 Novos dados sobre a Pré-história Antiga no concelho de Palmela. A intervenção arqueológica no sítio do Poceirão I

Michelle Teixeira Santos

757 Problemas em torno de Datas Absolutas Pré-Históricas no Norte do Alentejo Jorge de Oliveira

771 Povoamento pré-histórico nas áreas montanhosas do NO de Portugal: o Abrigo 1 de Vale de Cerdeira Pedro Xavier / José Meireles / Carlos Alves

783 Apreciação do povoamento do Neolítico Inicial na Baixa Bacia do Douro. A Lavra I (Serra da Aboboreira) como caso de estudo Maria de Jesus Sanches

797 O Processo de Neolitização na Plataforma do Mondego: os dados do Sector C do Outeiro dos Castelos de Beijós (Carregal do Sal)

João Carlos de Senna-Martinez / José Manuel Quintã Ventura / Andreia Carvalho / Cíntia Maurício

823 Novos trabalhos na Lapa da Bugalheira (Almonda, Torres Novas) Filipa Rodrigues / Pedro Souto / Artur Ferreira / Alexandre Varanda / Luís Gomes / Helena Gomes / João Zilhão

837 A pedra polida e afeiçoada do sítio do Neolítico médio da Moita do Ourives (Benavente, Portugal)

César Neves

857 Casal do Outeiro (Encarnação, Mafra): novos contributos para o conhecimento do povoamento do Neolítico final na Península de Lisboa.

Cátia Delicado / Carlos Maneira e Costa / Marta Miranda / Ana Catarina Sousa

873 Stresse infantil, morbilidade e mortalidade no sítio arqueológico do Neolítico Final/ Calcolítico ( $4^{\circ}$ e $3^{\circ}$ milénio a.C.) do Monte do Carrascal 2 (Ferreira do Alentejo, Beja) Liliana Matias de Carvalho / Sofia N. Wasterlain 
885 Come together: O Conjunto Megalítico das Motas (Monção, Viana do Castelo) e as expressões Campaniformes do Alto Minho Ana Catarina Basílio / Rui Ramos

899 Trabalhos arqueológicos no sítio Calcolítico da Pedreira do Poio Carla Magalhães / João Muralha / Mário Reis / António Batarda Fernandes

913 O sítio arqueológico de Castanheiro do Vento. Da arquitectura do sítio à arquitectura de um território João Muralha Cardoso

925 Estudo zooarqueológico das faunas do Calcolítico final de Vila Nova de São Pedro (Azambuja, Portugal): Campanhas de 2017 e 2018 Cleia Detry / Ana Catarina Francisco / Mariana Diniz / Andrea Martins / César Neves / José Morais Arnaud

943 As faunas depositadas no Museu Arqueológico do Carmo provenientes de Vila Nova de São Pedro (Azambuja): as campanhas de 1937 a 1967 Ana Catarina Francisco / Cleia Detry / César Neves / Andrea Martins / Mariana Diniz / José Morais Arnaud

959 Análise funcional de material lítico em sílex do castro de Vila Nova de S. Pedro (Azambuja, Portugal): uma primeira abordagem Rafael Lima

971 O recinto da Folha do Ouro 1 (Serpa) no contexto dos recintos de fossos calcolíticos alentejanos

António Carlos Valera / Tiago do Pereiro / Pedro Valério / António M. Monge Soares

\section{Proto-História}

987 Produção de sal marinho na Idade do Bronze do noroeste Português. Alguns dados para uma reflexão

Ana M. S. Bettencourt / Sara Luz / Nuno Oliveira / Pedro P. Simões / Maria Isabel C. Alves / Emílio Abad-Vidal

1001 A estátua-menir do Pedrão ou de São Bartolomeu do Mar (Esposende, noroeste de Portugal) no contexto arqueológico da fachada costeira de entre os rios Neiva e Cávado Ana M. S. Bettencourt / Manuel Santos-Estévez / Pedro Pimenta Simões / Luís Gonçalves

1015 O Castro do Muro (Vandoma/Baltar, Paredes) - notas para uma biografia de ocupação da Idade do Bronze à Idade Média

Maria Antónia D. Silva / Ana M. S. Bettencourt / António Manuel S. P. Silva / Natália Félix

1031 Do Bronze Final à Idade Média - continuidades e hiatos na ocupação de Povoados em Oliveira de Azeméis João Tiago Tavares / Adriaan de Man

1041 As faunas do final da Idade do Bronze no Sul de Portugal: leituras desde o Outeiro do Circo (Beja)

Nelson J. Almeida / Íris Dias / Cleia Detry / Eduardo Porfírio / Miguel Serra

1055 A Espada do Monte das Oliveiras (Serpa) - uma arma do Bronze Pleno do Sudoeste Rui M. G. Monge Soares / Pedro Valério / Mariana Nabais / António M. Monge Soares

1065 São Julião da Branca (Albergaria-a-Velha) - Investigação e valorização de um povoado do Bronze Final

António Manuel S. P. Silva / Paulo A. P. Lemos / Sara Almeida e Silva / Edite Martins de Sá

1083 Do castro de S. João ao Mosteiro de Santa Clara: notícia de uma intervenção arqueológica, em Vila do Conde Rui Pinheiro 
1095 O castro de Ovil (Espinho), um quarto de século de investigação - resultados e questões em aberto

Jorge Fernando Salvador / António Manuel S. P. Silva

1111 O Castro de Salreu (Estarreja), um povoado proto-histórico no litoral do Entre Douro e Vouga

Sara Almeida e Silva / António Manuel S. P. Silva / Paulo A. P. Lemos / Edite Martins de Sá

1127 Castro de Nossa Senhora das Necessidades (Sernancelhe): uma primeira análise artefactual Telma Susana O. Ribeiro

${ }_{1141}$ A cividade de Bagunte. O estado atual da investigação Pedro Brochado de Almeida

1153 Zoomorfos na cerâmica da Idade do Ferro no NW Peninsular: inventário, cronologias e significado Nuno Oliveira / Cristina Seoane

1163 Vasos gregos em Portugal: diferentes maneiras de contar a história do intercâmbio cultural na Idade do Ferro

Daniela Ferreira

1175 Os exotica da necrópole da Idade do Ferro do Olival do Senhor dos Mártires (Alcácer do Sal) no seu contexto regional

Francisco B. Gomes

\section{Antiguidade Clássica e Tardia}

1191 O uso de madeira como combustível no sítio da Quinta de Crestelos (Baixo Sabor): da Idade do Ferro à Romanização Filipe Vaz / João Tereso / Sérgio Simões Pereira / José Sastre / Javier Larrazabal Galarza / Susana Cosme / José António Pereira / Israel Espi

1207 Cultivos de Época Romana no Baixo Sabor: continuidade em tempos de mudança? João Pedro Tereso / Sérgio Simões Pereira / Filipe Santos / Luís Seabra / Filipe Vaz

1221 A casa romana na Hispânia: aplicação dos modelos itálicos nas províncias ibéricas Fernanda Magalhães / Diego Machado / Manuela Martins

1235 As pinturas murais romanas da Rua General Sousa Machado, n. ${ }^{5}$ 1, Chaves José Carvalho

1243 Trás do Castelo (Vale de Mir, Pegarinhos, Alijó) - Uma exploração agrícola romana do Douro

Tony Silvino / Pedro Pereira

1255 A sequência de ocupação no quadrante sudeste de Bracara Augusta: as transformações de uma unidade doméstica Lara Fernandes / Manuela Martins

1263 Os Mosaicos com decoração geométrica e geométrico-vegetalista dos sítios arqueológicos da área do Conuentus Bracaraugustanus. Novas abordagens quanto à conservação, restauro, decoração e datação Maria de Fátima Abraços / Licínia Wrench

1277 “Casa Romana” do Castro de São Domingos (Cristelos, Lousada): Escavação, Estudo e Musealização Paulo André de P. Lemos

1291 A arqueobotânica no Castro de Guifões (Matosinhos, Noroeste de Portugal): O primeiro estudo carpológico

Luís Seabra / Andreia Arezes / Catarina Magalhães / José Varela / João Pedro Tereso 
1305 Um Horreum Augustano na Foz do Douro (Monte do Castelo de Gaia, Vila Nova de Gaia) Rui Ramos

1311 Ponderais romanos na Lusitânia: padrões, formas, materiais e contextos de utilização Diego Barrios Rodríguez

1323 Um almofariz centro-itálico na foz do Mondego

Marco Penajoia

1335 Estruturas romanas de Carnide - Lisboa Luísa Batalha / Mário Monteiro / Guilherme Cardoso

1347 O contexto funerário do sector da "necrópole NO" da Rua das Portas de S. Antão (Lisboa): o espaço, os artefactos, os indivíduos e a sua interconectividade na interpretação do passado Sílvia Loja, José Carlos Quaresma, Nelson Cabaço, Marina Lourenço, Sílvia Casimiro, Rodrigo Banha da Silva, Francisca Alves-Cardoso

${ }_{1361}$ Povoamento em época Romana na Amadora - resultados de um projeto pluridisciplinar Gisela Encarnação / Vanessa Dias

1371 A Arquitectura Residencial em Mirobriga (Santiago do Cacém): contributo a partir de um estudo de caso Filipe Sousa / Catarina Felício

${ }_{1385}$ O fim do ciclo. Saneamento e gestão de resíduos nos edifícios termais de Mirobriga (Santiago do Cacém)

Catarina Felício / Filipe Sousa

1399 Balsa, Topografia e Urbanismo de uma Cidade Portuária Vítor Silva Dias / João Pedro Bernardes / Celso Candeias / Cristina Tété Garcia

1413 No Largo das Mouras Velhas em Faro (2017): novas evidências da necrópole norte de Ossonoba e da sua ocupação medieval Ricardo Costeira da Silva / Paulo Botelho / Fernando Santos / Liliana Nunes

1429 Instrumentos de pesca recuperados numa fábrica de salga em Ossonoba (Faro) Inês Rasteiro / Ricardo Costeira da Silva / Paulo Botelho

1439 A Necrópole Romana do Eirô, Duas Igrejas (Penafiel): intervenção arqueológica de 2016 Laura Sousa / Teresa Soeiro

1457 Ritual, descarte ou afetividade? A presença de Canis lupus familiaris na Necrópole Noroeste de Olisipo (Lisboa)

Beatriz Calapez Santos / Sofia Simões Pereira / Rodrigo Banha da Silva / Sílvia Casimiro / Cleia Detry / Francisca Alves Cardoso

1467 Dinâmicas económicas em Bracara na Antiguidade Tardia Diego Machado / Manuela Martins / Fernanda Magalhães / Natália Botica

1479 Cerâmicas e Vidros da Antiguidade Tardia do Edifício sob a Igreja do Bom Jesus (Vila Nova de Gaia) Joaquim Filipe Ramos

1493 Novos contributos para a topografia histórica de Mértola no período romano e na Antiguidade Tardia Virgílio Lopes

\section{8. Época Medieval}

1511 Cerâmicas islâmicas no Garb setentrional "português": algumas evidências e incógnitas Constança dos Santos / Helena Catarino / Susana Gómez / Maria José Gonçalves / Isabel Inácio / Gonçalo Lopes / Jacinta Bugalhão / Sandra Cavaco / Jaquelina Covaneiro / Isabel Cristina Fernandes / Ana Sofia Gomes 
1525 Contributo para o conhecimento da cosmética islâmica, em Silves, durante a Idade Média Rosa Varela Gomes

1537 Yábura e o seu território - uma análise histórico-arqueológica de Évora entre os séculos VIII-XII José Rui Santos

1547 A encosta sul do Castelo de Palmela - resultados preliminares da escavação arqueológica Luís Filipe Pereira / Michelle Teixeira Santos

1559 A igreja de São Lourenço (Mouraria, Lisboa): um conjunto de silos e de cerâmica medieval islâmica

Andreia Filipa Moreira Rodrigues

1571 O registo material de movimentações populacionais no Médio Tejo, durante os séculos XII-XIII. Dois casos de "sunken featured buildings", nos concelhos de Cartaxo e Torres Novas Marco Liberato / Helena Santos / Nuno Santos

1585 O nordeste transmontano nos alvores da Idade média. Notas para reflexão Ana Maria da Costa Oliveira

1601 Sepulturas escavadas na rocha do Norte de Portugal e do Vale do Douro: primeiros resultados do Projecto SER-NPVD

Mário Jorge Barroca / César Guedes / Andreia Arezes / Ana Maria Oliveira

1619 "Portucalem Castrum Novum" entre o Mediterrâneo e o Atlântico: o estudo dos materiais cerâmicos alto-medievais do arqueossítio da rua de D. Hugo, nํ. 5 (Porto) João Luís Veloso

1627 A Alta Idade Média na fronteira de Lafões: notas preliminares sobre a Arqueologia no Concelho de Vouzela

Manuel Luís Real / Catarina Tente

1641 Um conjunto cerâmico medieval fora de portas: um breve testemunho aveirense Susana Temudo

${ }_{1651}$ Os Lóios do Porto: uma perspetiva integrada no panorama funerário da Baixa Idade Média à Época Moderna em meios urbanos em Portugal

Ana Lema Seabra

1659 O Caminho Português Interior de Santiago como eixo viário na Idade Média Pedro Azevedo

1665 Morfologia Urbana: Um exercício em torno do Castelo de Ourém André Donas-Botto / Jaqueline Pereira

1677 Intervenção arqueológica na Rua Marquês de Pombal/Largo do Espírito Santo (Bucelas, Loures)

Florbela Estêvão / Nathalie Antunes-Ferreira / Dário Ramos Neves / Inês Lisboa

1691 O Cemitério Medieval do Poço do Borratém e a espacialidade funerária na cidade de Lisboa Inês Belém / Vanessa Filipe / Vasco Noronha Vieira / Sónia Ferro / Rodrigo Banha da Silva

1705 Um Espaço Funerário Conventual do séc. XV em Lisboa: o caso do Convento de São Domingos da Cidade Sérgio Pedroso / Sílvia Casimiro / Rodrigo Banha da Silva / Francisca Alves Cardoso

\section{9. Época Moderna e Contemporânea}

1721 Arqueologia Moderna em Portugal: algumas reflexões críticas em torno da quantificação de conjuntos cerâmicos e suas inferências históricas e antropológicas Rodrigo Banha da Silva / André Bargão / Sara da Cruz Ferreira

1733 Faianças de dois contextos entre os finais do século XVI e XVIII do Palácio dos Condes de Penafiel, Lisboa

Martim Lopes / Tomás Mesquita 
1747 Um perfil de consumo do século XVIII na foz do Tejo: O caso do Mercado da Ribeira, Lisboa Sara da Cruz Ferreira / Rodrigo Banha da Silva / André Bargão

1761 Os Cachimbos dos Séculos XVII e XVIII do Palácio Mesquitela e Convento dos Inglesinhos (Lisboa)

Inês Simão / Marina Pinto / João Pimenta / Sara da Cruz Ferreira / André Bargão / Rodrigo Banha da Silva

1775 "Tomar os fumos da erua que chamão em Portugal erua sancta». Estudo de Cachimbos provenientes da Rua do Terreiro do Trigo, Lisboa

Miguel Martins de Sousa / José Pedro Henriques / Vanessa Galiza Filipe

1787 Cachimbos de Barro Caulínitico da Sé da Cidade Velha (República de Cabo Verde)

Rodrigo Banha da Silva / João Pimenta / Clementino Amaro

1801 Algumas considerações sobre espólio não cerâmico recuperado no Largo de Jesus (Lisboa) Carlos Boavida

1815 Adereços de vidro, dos séculos XVI-XVIII, procedentes do antigo Convento de Santana de Lisboa (anéis, braceletes e contas)

Joana Gonçalves / Rosa Varela Gomes / Mário Varela Gomes

1837 Da ostentação, luxo e poder à simplicidade do uso quotidiano: arqueologia e simbologia de joias e adornos da Idade Moderna Portuguesa Jéssica Iglésias

1849 Os amuletos em Portugal - dos objetos às superstições: o coral vermelho Alexandra Vieira

1865 Cerâmicas de Vila Franca de Xira nos séculos XV e XVI Eva Pires

1879 «Não passa por teu o que me pertence». Marcas de individualização associadas a faianças do Convento de Nossa Senhora de Aracoeli, Alcácer do Sal Catarina Parreira / Íris Fragoso / Miguel Martins de Sousa

1891 Cerâmica de Leiria: alguns focos de produção

Jaqueline Pereira / André Donas-Botto

1901 Os Fornos na Rua da Biquinha, em Óbidos Hugo Silva / Filipe Oliveira

1909 A casa de Pêro Fernandes, contador dos contos de D. Manuel I: o sítio arqueológico da Silha do Alferes, Seixal (século XVI) Mariana Nunes Ferreira

1921 O Alto da Vigia (Sintra) e a vigilância e defesa da costa Alexandre Gonçalves / Sandra Santos

1937 O contexto da torre sineira da Igreja de Santa Maria de Loures Paulo Calaveira / Martim Lopes

1949 A Necrópole do Hospital Militar do Castelo de São Jorge e as práticas funerárias na Lisboa de Época Moderna Susana Henriques / Liliana Matias de Carvalho / Ana Amarante / Sofia N. Wasterlain

1963 SAND - Sarilhos Grandes Entre dois Mundos: o adro da Igreja e a Paleobiologia dos ossos humanos recuperados

Paula Alves Pereira / Roger Lee Jesus / Bruno M. Magalhães

1975 Expansão urbana da vila de Cascais no século XVII e XVIII: a intervenção arqueológica na Rua da Vitória no 15 a 17

Tiago Pereira / Vanessa Filipe

1987 Novos dados para o conhecimento do Urbanismo de Faro em época Moderna Ana Rosa 
1995 Um exemplo de Arqueologia Urbana em Alcoutim: o Antigo Edifício dos CTT Marco Fernandes / Marta Dias / Alexandra Gradim / Virgílio Lopes / Susana Gómez Martínez

2007 Palácio dos Ferrazes (Rua das Flores/Rua da Vitória, Porto): a cocheira de Domingos Oliveira Maia

Francisco Raimundo

2021 As muitas vidas de um edifício urbano: História, Arqueologia e Antropologia no antigo Recreatório Paroquial de Penafiel Helena Bernardo / Jorge Sampaio / Marta Borges

2035 O convento de Nossa Senhora da Esperança de Ponta Delgada: o contributo da arqueologia para o conhecimento de um monumento identitário João Gonçalves Araújo / N’Zinga Oliveira

2047 Arqueologia na ilha do Corvo... em busca da capela de Nossa Senhora do Rosário Tânia Manuel Casimiro / José Luís Neto / Luís Borges / Pedro Parreira

2059 Perdidos à vista da Costa. Trabalhos arqueológicos subaquáticos na Barra do Tejo Jorge Freire / José Bettencourt / Augusto Salgado

2071 Arqueologia marítima em Cabo Verde: enquadramento e primeiros resultados do projecto CONCHA

José Bettencourt / Adilson Dias / Carlos Lima / Christelle Chouzenoux / Cristóvão Fonseca / Dúnia Pereira / Gonçalo Lopes / Inês Coelho / Jaylson Monteiro / José Lima / Maria Eugénia Alves / Patrícia Carvalho / Tiago Silva

2085 Trabalhos arqueológicos na Cidade Velha (Ribeira Grande de Santiago, Cabo Verde): reflexões sobre um projecto de investigação e divulgação patrimonial André Teixeira / Jaylson Monteiro / Mariana Mateus / Nireide Tavares / Cristovão Fonseca / Gonçalo C. Lopes / Joana Bento Torres / Dúnia Pereira / André Bargão / Aurélie Mayer / Bruno Zélie / Carlos Lima / Christelle Chouzenoux / Inês Henriques / Inês Pinto Coelho / José Lima / Patrícia Carvalho / Tiago Silva

2103 A antiga fortificação de Quelba / Khor Kalba (E.A.U.). Resultados de quatro campanhas de escavações, problemáticas e perspectivas futuras Rui Carita / Rosa Varela Gomes / Mário Varela Gomes / Kamyar Kamyad

2123 Colónias para homens novos: arqueologia da colonização agrária fascista no noroeste ibérico Xurxo Ayán Vila / José Mạ . Señorán Martín 


\title{
NOVOS CONTRIBUTOS PARA A TOPOGRAFIA HISTÓRICA DE MÉRTOLA NO PERÍODO ROMANO E NA ANTIGUIDADE TARDIA
}

\author{
Virgílio Lopes ${ }^{1}$
}

\begin{abstract}
RESUMO
No presente trabalho pretende-se fazer uma abordagem às novidades arqueológicas ocorridas nos últimos anos em Mértola, dando a conhecer os resultados obtidos e o seu contributo para o conhecimento da cultura material e da topografia histórica da cidade de no Período Romano e na Antiguidade Tardia. Palavras-chave: Estatuária romana, Fora, Complexo religioso, Criptopórtico, Torre do Rio.
\end{abstract}

\begin{abstract}
This paper is intended to show the archaeological discoveries made in the last years in Mértola, in order to show the results and its' contributions to the knowledge of the material culture and historical topography of the city of Myrtilis in the Roman Ages and Late Antiquity.

Keywords: Roman statuary, Fora, Religious complex, Cryptoportic, River Tower.
\end{abstract}

\section{INTRODUÇÃO}

O casco histórico da vila de Mértola tem a nascente o rio Guadiana e a poente a ribeira de Oeiras. O rio Guadiana foi a grande via fluvial que ligava Mértola ao litoral algarvio e, consequentemente, ao Atlântico e ao Mediterrâneo. O facto das marés se fazerem sentir até Mértola, o que provoca uma oscilação diária do nível do rio de cerca de dois metros junto à vila, favorecia a navegação de vários tipos de barcos até ao "porto fluvial mais a norte da grande estrada que era o Guadiana" (Torres, 1992, p. 190; Boiça, 1993, p. 47). Ao analisarmos as gravuras quinhentistas de Duarte D’ Armas é possível observar nesta linha de água, barcos com três mastros, o que indica boas possibilidades de navegação para embarcações de alguma dimensão e capacidade de transporte de mercadorias (Almeida, 1943, p. 31-37). A ligação ao porto era feita, em período romano, pela Porta da Ribeira. Esta, como é visível nas gravuras, era constituída por uma porta em cotovelo encimada por um torreão cuja demolição só aconteceria em meados do século XIX (Boiça, 1993, p. 59). Esta lógica funcional só é alterada em meados do século, quando se procedeu à construção do cais atual e se abriu uma estrada de acesso. Com esta remodelação urbanística, também o local de travessia do rio se alterou, e assim a construção do cais levou a que, nas suas imediações, se instalasse a "ponte barca", que substituiu a velha travessia do Guadiana que anteriormente se fazia junto à Torre do Rio (Figura 1).

\section{A CIDADE NO PERÍODO ROMANO}

A muralha atual tem um perímetro de cerca de 1.291 metros e abarca uma área de cerca de $50.000 \mathrm{~m}^{2}$, ou seja, aproximadamente 5 hectares. Neste recinto são identificáveis quatro acessos, a porta da Acrópole, a porta de Beja, a porta da Ribeira, a porta do Buraco, que devem corresponder às portas existentes desde os tempos romanos (Lopes, 2012, p. 26).

Um dos possíveis fora de Myrtilis localizava-se na plataforma artificial situada na extremidade noroeste da cidade. Nesta zona foram identificados, até ao

1. Campo Arqueológico de Mértola, Centro de Estudos em Arqueologia Artes e Ciências do Património, Bolseiro Pós-Doutoramento da Fundação para a Ciência e a Tecnologia. 
momento, vestígios de uma basílica (localizada na parte noroeste), um possível templo nas proximidades da atual igreja cristã e ainda o criptopórtico (Torres \& Oliveira, 1987, pp. 618-626). Esta plataforma era delimitada pelas seguintes estruturas: a poente, por duas muralhas paralelas; no limite norte, pelo criptopórtico e por uma muralha onde se insere uma porta monumental.

$\mathrm{Na}$ parte virada a nascente, os trabalhos arqueológicos trouxeram à luz uma possível porta de acesso ao forum e ainda um conjunto de seis "arcossólios", cuja técnica construtiva se assemelha à alvenaria do criptopórtico, delimitavam esta praça, ou seriam o elemento estruturante de uma plataforma capaz de vencer a forte inclinação da topografia original.

A porta situada a norte do forum e que a este dava acesso, apesar de incompleta e parcialmente escavada, demonstra bem a monumentalidade da construção. Apresenta uma largura de quatro metros e meio e descreve um arco de pleno centro cujas aduelas são constituídas por tijolos de grandes dimensões ${ }^{2}$. A porta foi posteriormente adaptada e introduzido um novo sistema de fecho em cataratae. O interior desta estrutura utiliza um aparelho de técnica mista onde o xisto é também utilizado com abundância. A muralha onde esta porta se inscreve possui aproximadamente três metros de largura. A porta inevitavelmente conduziria a uma rua, o que criava duas plataformas com cotas diferentes (Figura 2).

No que concerne aos edifícios públicos, destaca-se a possível basílica localizada na parte poente da plataforma. Composta por um corpo retangular e delimitado a oeste por uma ábside semicircular, apresenta na sua parte conservada 21 metros de comprimento e 7 metros de largura. A parede sul eleva-se a cerca de cinco metros. No pavimento que foi revestido de mosaicos, ainda é visível, num dos ângulos da abside, uma base de coluna em mármore. São vários os elementos arquitetónicos, dispersos ou reutilizados, que apontam para a existência de um templo romano localizado no mesmo local onde se ergueu a mesquita e onde hoje se encontra a igreja matriz.

A nível da arquitetura doméstica de Myrtilis, os dados disponíveis resumem-se apenas a uma "casa romana”, escavada na década de oitenta do século XX no subsolo da Câmara Municipal (onde hoje está

2. Comprimento $43 \mathrm{~cm}$, largura $30 \mathrm{~cm}$, espessura $6 \mathrm{~cm}$, dispostos em fiadas que alternam com fiadas de alvenaria de pedra e argamassa. instalado o núcleo museológico correspondente) e, entre 1994 e 2004, na intervenção arqueológica realizada no edifício contíguo a poente, na chamada "Casa do Lanternim». A escavação arqueológica não permitiu esclarecer muitas questões, dada a impossibilidade de prosseguir sob as construções vizinhas e a rua que as separa, no entanto, conseguimos determinar que esta casa teve dois níveis distintos de ocupação: um mais antigo, possivelmente de época imperial, e um outro, posterior ao século III d.C. O certo é que no extremo da "casa romana" se deteta a existência de um impluvium mais antigo que foi completamente recoberto por um opus signinum compacto, ainda hoje visível, com o objetivo de o adaptar a tanque ou lago interior. Esse impluvium certamente ocuparia também a rua que hoje separa essa casa da do Lanternim (Lopes, 2012).

\section{OS NOVOS DADOS DA ARQUEOLOGIA}

Entre 2017 e 2018 foram levadas a cabo as escavações na chamada Casa Cor de Rosa, um imóvel construído nos finais do século XIX e inícios do seguinte. Este edifício situa-se na Rua 5 de Outubro (com os números $7,7 \mathrm{~A}$ e $7 \mathrm{~B}$ ), é uma das maiores casas do centro histórico da vila de Mértola, e inclui, para além da zona coberta, um quintal, anexos e uma cisterna que ocupam uma área total $742 \mathrm{~m}^{2}$. Mandada edificar por Manuel Francisco Gomes, um grande comerciante local, com barcos próprios a circular no rio Guadiana, tinha no piso térreo da sua habitação um grande armazém onde se guardavam consideráveis quantidades de cereais.

A escavação arqueológica começou na zona do quintal onde foi identificada e escavada uma fossa séptica utilizada como depósito do lixo hospitalar do então consultório médico do Dr. Francisco Gomes, médico no concelho de Mértola entre 1927 e 1970. Seguiram-se trabalhos de escavação no piso térreo onde foi possível uma intervenção numa área $193 \mathrm{~m}^{2}$ e com níveis variáveis tendo, em alguns casos, ultrapassado os 4 metros de profundidade.

A intensa ocupação humana do casco urbano de Mértola gerou uma complexa e rica estratigrafia arqueológica. Contudo, dada a imprevisibilidade deste tipo de intervenções em contexto urbano, constatou-se, mais uma vez, que as estruturas encontradas se prolongam em várias direções, pelas construções e ruas adjacentes, fazendo com que, na maioria dos casos, as interrogações persistam; noutros permite-nos a 
articulação com informação já existente, proveniente de trabalhos arqueológicos realizados anteriormente em edifícios situados nas imediações, e a colocação de novas hipóteses de leitura diacrónica do espaço.

Nos níveis mais profundos foram identificadas construções monumentais do período romano, sendo possível observar três momentos construtivos. Um primeiro, do qual resta parte de um tanque de canto arredondado, constituído por uma espessa camada de opus signinum (geralmente associado a estruturas hidráulicas), no qual estavam agregados muros de alvenaria de lajes de xisto dispostas na horizontal, ligadas por terra e muito bem facetadas. Este tanque foi cortado pela construção posterior, possivelmente um templo, com paredes cuja largura ronda os dois metros, e que está associado ao conjunto escultórico do século I. d.C., o que quer dizer que terá uma cronologia anterior.

Do segundo momento construtivo foi identificada uma edificação de forma retangular, com 12 metros no seu lado maior e 10,75 metros no lado menor, com muros com uma espessura entre os 1,5 e os 3 metros, não sendo possível determinar toda a extensão do edifício, já que este se prolonga para as construções vizinhas. Parte dessa construção romana, situada na sala correspondente ao número $7 \mathrm{~B}$, apresenta, em dois pontos distintos, uma destruição motivada pelo facto do seu principal material construtivo - a pedra - ter sido retirada para ser utilizada em construções posteriores.

Numa terceira fase, foi acrescentada aos muros laterais uma outra estrutura de alvenaria argamassada, com 50 centímetros de largura. Estes muros são constituídos por pedra de xisto aparelhada e ligada por uma forte argamassa, sendo pontualmente utilizados silhares de granito e blocos de arenito. Na parede nordeste conservam-se restos da argamassa de revestimento com vestígios de pintura com cores distintas (vermelho, creme e preto). A composição é formada por painéis retangulares onde apenas são percetíveis as molduras lineares (vermelho e preto) e as barras verticais de vermelho "pompeiano". No canto nordeste da Casa Cor de Rosa, a cerca de 4 metros de profundidade, numa cova propositadamente aberta para o efeito, foi descoberto um conjunto escultórico, constituído por uma estátua masculina, incompleta, de grandes proporções, que enverga trajes militares, de tipo Thoracata e por três estátuas femininas, tendo uma delas proporções idênticas (Figura 3). Junto à estrutura absidada, foram encontrados uma cabeça feminina e um fragmento de braço envolto na toga, a par de vários fragmentos escultóricos, disformes e de reduzidas dimensões. A qualidade escultórica em termos estéticos, técnicos e dos materiais constituintes - mármore branco - podem enquadrar estas esculturas na primeira metade do século I d.C. Os dados planimétricos obtidos apontam para uma estrutura monumental, de caráter público, possivelmente um templo. A razão que sustenta esta hipótese está relacionada com a dimensão das construções identificadas capazes de comportar edificações de grande envergadura e volumetria. Por outro lado, em 2007 e 2008, no decurso da obra de recuperação da Casa Fagulha ${ }^{3}$, localizada nas proximidades, foram detetadas estruturas que parecem ter correspondência e situar-se no mesmo alinhamento destas, e que podem, eventualmente, constituir o prolongamento deste edifício.

Uma constatação interessante é a existência de uma camada espessa de terra exógena, que serviu para o nivelamento da topografia pré-existente e sobre a qual se edificaram as distintas construções. A existência desta terra alaranjada com pequenos módulos petrificados parece-nos provir de zonas exteriores ao território de Mértola, podendo ser originária da zona costeira. Este tipo de terra foi encontrado nos níveis mais antigos da escavação da casa cor de rosa e nas intervenções levadas a cabo nas casas da Rua Professor Batista da Graça, nas imediações da igreja da Misericórdia, na parte baixa do casco histórico.

A monumentalidade das estruturas arqueológicas identificadas, a que acresce este fabuloso conjunto escultórico, permite-nos deduzir que podemos estar na presença de um templo integrado num conjunto monumental do tipo forum. Esta ideia é reforçada pelo achado, nos finais do século do XIX, aquando da construção da mesma Casa Cor de Rosa, de uma outra estátua de togado, que se encontra em exposição no núcleo museológico Casa Romana, situado no edifício dos Paços do Concelho na Praça Luís de Camões. De referir ainda a importante localização topográfica, na proximidade da porta de ligação de Mértola ao rio Guadiana e à antiga zona portuária (Figura 4).

Duas estruturas da Antiguidade Tardia foram localizadas no canto norte do mesmo edifício. São constituídas por muros de alvenaria de pedra vã, sendo

3. Obra de requalificação a cargo do Município de Mértola com a intervenção arqueológica de Jorge Feio. 
num deles visíveis elementos arquitetónicos e fragmentos de estatuária romana, em mármore. Uma vez desmontada a primeira, foram removidas duas bases de estátua, um elemento de friso marmóreo de grandes dimensões e alguns fragmentos de estatuária, nomeadamente a parte inferior de uma estátua e vários fragmentos correspondentes a restos de panejamentos.

A segunda estrutura situada nesse sítio, apresenta uma planta absidada, que envolve uma outra, que forma um canto perfeitamente retilíneo. Estas estruturas correspondem a muros bem construídos, em blocos de xisto bem facetados, ligados com terra. No embasamento desta estrutura foi reutilizado um grande bloco de mármore, possivelmente um elemento de friso e, por debaixo deste, identificado aquando do desmonte, um numisma de Graciano, cunhado em Aquileia e datado entre $379-383^{4}$. Este achado fornece uma datação importante para o desmantelamento do complexo monumental do período romano e a ocultação das estátuas, mas também o momento da construção das estruturas da Antiguidade Tardia.

Dos novos achados escultóricos, ocultados numa fossa, fazem parte: a parte superior das pernas e o dorso duma estátua masculina, de tipo Thoracata, partida em duas partes; um fragmento do pé esquerdo, descalço, sobre a base e ainda um grande fragmento com restos do braço esquerdo de onde pendem os panejamentos; três estátuas femininas, uma de grandes proporções (cerca de $152 \mathrm{~cm}$ conservados) apresenta apenas a parte inferior, bacia, pernas e pés assentes numa base, outra que parece ser de uma jovem (assente numa base incompleta e com $139 \mathrm{~cm}$ de altura), apresenta parte do pescoço, do que se depreende que seria uma estátua inteira e não como a maior parte dos casos conhecidos, que estavam preparadas para a colocação de diferentes cabeças; a terceira estátua feminina, incompleta, (tem altura conservada de $120 \mathrm{~cm}$ ), apresenta vestuário ricamente adornado e uma fíbula no ombro direito, podendo a base ser um fragmento encontra-

4. AE2. D N GRATIA-NVS P F AVG, diadema de pérola, drapeado, com o busto virado para o lado direito / REPARATIO REIPVB, Graciano em pé na frente, cabeça para a esquerda, oferecendo a mão direita à mulher ajoelhada, na mão esquerda segura uma Victoria com um globo. http://www.wildwinds.com/coins/ric/gratian/_siscia_ RIC_O26a_mm4.jpg http://www.wildwinds.com/coins/ ric/gratian/t.html (consultado em 10. 1.2019) do nas imediações, em que estão esculpidos os restos de vestes (Figura 5).

Noutro local da mesma Casa, próximo do anterior, apareceu uma cabeça feminina (com cerca de $43 \mathrm{~cm}$ de altura), de mármore branco de excelente qualidade e tratamento escultórico, que se encontra danificada na zona do nariz. Nas proximidades desta peça encontrou-se um fragmento de braço que segura um panejamento. É de considerar a hipótese de se tratar da cabeça de Lívia, esposa de Augusto a sua métrica é enquadrável na peça feminina de maiores proporções (Lopes, 2018b, pp. 34-41).

À monumental estátua thoracata poderá ter pertencido a cabeça de Augusto, descoberta em Mértola, em data incerta e que hoje se encontra no Museu Nacional de Arqueologia ${ }^{5}$, em Lisboa. Contudo, a observação desta peça permite perceber que foi desbastada, na zona do pescoço, e encaixada no togado proveniente de Mértola. Esta composição forçada esteve em exposição nos anos sessenta do século XX no referido museu e está documentada fotograficamente num artigo de Garcia e Bellido, num texto publicado no Arquivo de Beja. O togado está encimado com a cabeça de Augusto e na estátua feminina de orante foi colocada a cabeça de Cibele, interpretada erradamente como sendo Lívia (Garcia y Bellido, 1966, p. 28o-282, figs. 1 e 2).

Tendo em conta a métrica da estátua e da cabeça e o facto do pescoço de Augusto terminar num espigão arredondado e o thoracata ter um recetáculo côncavo, podemos supor que as duas peças pertenceriam a uma só. A verificar-se esta hipótese de trabalho, teríamos em Mértola um templo do culto imperial criado por Augusto.

Nesta estátua envergando traje militar, de pé e numa atitude solene, destaca-se a decoração da sua armadura, constituída na parte superior por um relevo representando a Medusa, a que se segue o peitoral decorado com duas vitórias aladas defrontadas, uma que segura e outra que alimenta um queimador. Na parte inferior, os pterigia estão dispostos em três fileiras, sendo a sua decoração constituída por figuras e bustos humanos, figuras mitológicas, motivos vegetais e animais como águias e cabeças de lince. Este animal também possui representações em estátuas da mesma tipologia na Guarda, Mérida,

5. http://www.matriznet.dgpc.pt/MatrizNet/Objectos/ ObjectosConsultar.aspx?IdReg=110213 (consultado em 10. 12.2017) 
Baeza e Verona. Na parte inferior do corpo ainda são visíveis restos de panejamento e da perna esquerda, e dela poderão também fazer parte os restos de um pé descalço de grandes dimensões o que, a pertencer a esta peça, nos indica que esta se encontraria no interior do templo.

Ainda relacionadas com estes exemplares escultóricos estão as duas bases de mármore reutilizadas numa estrutura murária, a par de vários fragmentos escultóricos. Poderia tratar-se de plintos que serviram de elementos de suporte para as estátuas.

\section{A CIDADE NA ANTIGUIDADE TARDIA O CRIPTOPÓRTICO - CISTERNA}

Na plataforma artificial, onde o desnível era compensado pelo pano de muralha construída com silharia, foi implantada uma construção subterrânea designada por criptopórtico-cisterna, que inicialmente era um sítio de passagem. A descoberta desta construção foi feita no início do século XVI, por Duarte D’Armas que anota no seu "Livro das Fortalezas" o seguinte: aqui esta huã abobada atopida muyto booa (Branco, 1997, p. 6). Três séculos mais tarde Estácio da Veiga faz a seguinte descrição da parede exterior do criptopórtico: começam a manifestar-se no revestimento externo varias pedras, incluindo belos mármores, que bem significam haver pertencido a nobres edificios. Quasi toda a cortina adherente ao baluarte fronteiro à ermida da Senhora das Neves é abundante d' esta mescla, incluindo espaçosas pedras rectangulares de granito, que necessariamente vieram de grande distancia e não para construcção das muralhas (Veiga, 1983, p. 78).

Os trabalhos de escavação levados a cabo pelo Campo Arqueológico de Mértola (CAM), em finais dos anos setenta do século XX, no interior desta estrutura, que "foi minuciosamente desentulhada durante cinco anos" (Torres \& Silva, 1989, p. 31), revelaram uma galeria com um papel essencialmente estrutural, de contenção e suporte da plataforma de implantação do forum. Assim, no lado norte, para suportar maiores pressões numa amplitude mais vasta, o desnível era compensado por um criptopórtico de $32 \mathrm{~m}$ de comprimento, com largura e altura médias de, respetivamente, 2,70 e 5,80 m (Torres \& Oliveira: 1987, 618).

A feição assumidamente militar do conjunto galeriacriptopórtico e muro-exterior, não parece suscitar dúvidas. Para isso aponta a sua localização, a solidez da construção e ainda as quatro aberturas na muralha (estando uma ainda entaipada) que poderão ter funcionado como seteiras, podendo o criptopórtico ser uma espécie de "casamata" no caso da cidade ser sujeita a assédio militar.

Por esclarecer está ainda a ligação do criptopórtico à porta de acesso do forum, na parte nordeste da plataforma, pois só novos trabalhos arqueológicos nessa área a poderão revelar. No entanto, pela abertura existente no topo este do criptopórtico, é possível inferir que este se prolongaria nessa direção. Tão pouco está completamente esclarecida a contribuição que as remodelações dos torreões medievais podem ter dado para a destruição do criptopórtico nos seus dois topos.

Mais tarde o criptopórtico foi redimensionado e sofreu um programa de obras que lhe modificou as funções. Refira-se que são notórios dois momentos distintos desta construção: um primeiro, em que são erguidas as paredes do criptopórtico e, outro posterior, em que ambos os topos são fechados. No topo leste é visível essa diferença. Depois de redimensionado esse espaço, o pavimento e a parte inferior das paredes, até uma altura entre 1,50 e 1,70 m, foram revestidos por uma sólida argamassa impermeável tipo opus signinum e as quatro "seteiras" entaipadas com o evidente objetivo de adaptar o espaço a cisterna. Este entaipamento poderá ser enquadrável, cronologicamente, nos finais do século IV ou inícios do $\mathrm{V}$, em data não muito distante da sua construção inicial (Macias, 1996, p. 53).

A cisterna tinha uma capacidade para armazenamento de $138 \mathrm{~m}^{3}$ de água (Macias, 1996, p. 53). O encerramento dos topos da galeria foi feito com paredes de alvenaria e pela análise da técnica construtiva destes entaipamentos, é notório que se trata de intervenções posteriores, pois as pedras que formam os cantos apenas encostam às paredes do criptopórtico, não havendo qualquer espécie de travamento entre elas. Por um orifício existente na parte superior da parede é possível observar que a abóbada se prolongava para além do entaipamento. Questões de segurança impedem-nos, porém, de prosseguir com trabalhos de escavação que permitissem investigar a existência dessa estrutura subterrânea. O entaipamento das quatro seteiras teve certamente como objetivo proteger as águas, evitando a entrada de aves e outros animais.

De uma das seteiras entaipadas foi removido um capitel de grandes dimensões, finamente decorado 
com motivo liriforme. Este elemento arquitetónico é possivelmente originário de um edifício público do forum da cidade, e é enquadrável cronologicamente no século II - III (Lopes, 2012, p. 83).

A hipótese que coloco situa a adaptação do criptopórtico a cisterna como coetânea da construção do complexo baptismal. A cisterna aproveitava a água das chuvas provenientes dos edifícios situados na plataforma superior. A sustenta esta hipótese está o facto de, no muro sul da galeria porticada, em ambas as extremidades, existirem duas aberturas rasgadas nos muros e que deveriam ser o remate de um sistema de algerozes que recolhiam dos telhados a água das chuvas e a conduzia para esses pontos. O facto destas aberturas terem sido escavadas nos muros e perfurarem a abóbada do criptopórtico, sugerem tratar-se de um momento posterior de adaptação do espaço a cisterna (Figura 6).

\section{O COMPLEXO RELIGIOSO}

Durante os séculos V - VI d.C. na zona da antiga acrópole, as construções do possível forum foram remodeladas e adaptadas às novas necessidades criadas com a introdução do Cristianismo. Na parte oeste da plataforma foi erguido um complexo de edifícios para albergar dois monumentais batistérios. Para além das piscinas batismais, chegaram até aos nossos dias vestígios de pavimentos adornados com painéis de mosaicos, onde não faltava a policromia das tesselas ou dos frescos de que restam vestígios. O complexo religioso era constituído pela sala do batistério, um compartimento anexo situado a norte, uma passagem em cotovelo e um espaço que ladeava a ábside; a sul e a norte é delimitado, respetivamente, por um compartimento de planta basilical e uma galeria porticada (Figura 7).

A parte do complexo religioso da Alcáçova, onde ainda hoje se podem admirar belos mosaicos paleocristãos, assenta sobre uma construção subterrânea designada por criptopórtico/cisterna. Esta edificação é referida por Duarte de Armas, no início do século XVI, que anota: aqui esta huã abobada atopida muyto boa (Almeida, 1943). Trata-se duma galeria com um papel essencialmente estrutural, de contenção e suporte da plataforma de implantação do forum (Torres \& Oiveira:1987, p. 618; Torres \& Silva, 1989, p.31). O pavimento da galeria porticada e o deambulatório estavam cobertos por um significativo conjunto musivo, do qual realçamos, no deambu- latório, Belerofonte cavalgando o Pégaso para matar a Quimera e, no longo corredor porticado, dois leões afrontados e várias cenas de caça com um cavaleiro empunhando um falcão (Lopes, 2003). Se a falta de paralelos bem datados inviabiliza uma cronologia segura, leituras estratigráficas e traços estilísticos permitem atribuir esta obra à primeira metade do século VI d.C.

O edifício de planta retangular continha no seu interior um batistério octogonal, implantado no centro de um tanque ou piscina e rodeado por um deambulatório, no qual se abria a leste uma ábside de planta em arco ultrapassado. A pia batismal, de desenho octogonal, onde se recortam, pelo exterior, oito pequenos absidíolos, é constituída, no seu interior, por uma pequena piscina, também oitavada, onde um ressalto em degrau serviria de assento ${ }^{6}$. O sistema hidráulico de abastecimento do batistério, supomos que se efetuaria com recurso a tubagens inseridas numa canalização em alvenaria ${ }^{7}$. De seguida a água era conduzida para uma pequena pia quadrangular existente no fundo, no lado sul, com as dimensões interiores de $30 \mathrm{~cm}$ de lado. Posteriormente a água seguiria por uma tubagem até ao pináculo perfurado, localizado no centro da piscina batismal, por onde jorraria (Figura 8).

Como todo este conjunto arquitetónico se encontra numa cota inferior, por ação da gravidade a água, trazida por uma conduta, da qual só resta o negativo do seu assentamento, penetrava no interior da pia, onde poderia jorrar através de um pequeno pináculo fixado no fundo; sendo que as águas utilizadas escorriam para uma fossa estreita com 2,80 $\mathrm{m}$ de profundidade. No fundo são visíveis restos de reboco de argamassa em opus signinum e as paredes laterais são de alvenaria de xisto, onde se notam, encastrados, alguns fragmentos de uma imposta e de um fuste de coluna em mármore.

Com os trabalhos arqueológicos do verão de 2013, um pouco mais acima, na encosta do Castelo de Mértola, surgiu parte de um novo edifício de cabeceira tripartida e planta retangular. Este edifício

\footnotetext{
6. A altura máxima desta pia batismal era 1,07 metros, a largura interior varia entre 1,12 metros na base e 1,50 no topo. No exterior as medidas no eixo norte-sul são 3,50 e este-oeste 4,46 metros.

7. Possui uma altura situada em torno dos $27 \mathrm{~cm}$ e uma largura de $22 \mathrm{~cm}$ e entrava na piscina por um orifício de $15 \mathrm{x}$ $15 \mathrm{~cm}$.
} 
envolvia uma monumental estrutura batismal de forma octogonal, cujo interior apresenta quatro degraus revestidos com placas de mármores ${ }^{8}$. No lado norte da piscina foi aberta, numa fase posterior, um pequeno tanque quadrado, rematado exteriormente por um pequeno absidíolo e por uma cancela vazada para o interior. Do lado oposto deveria haver outra cancela, mas só restam alguns fragmentos de ferro que eventualmente serviriam para a sustentar. Este pequeno tanque absidíolo tanto poderia ser o local para a colocação de um membro do clero que auxiliasse o neófito na imersão batismal como poderia estar relacionado com o batismo de crianças. Esta última possibilidade pode justificar a existência do pequeno tanque que se encontra ao lado (Figura 9). No lado ocidental, o tanque octogonal possui um orifício de escoamento na placa de mármore colocada na vertical. Neste ponto apenas resta o negativo da tubagem metálica, entretanto desaparecida. A canalização, constituída por imbrices, segue depois para norte, por debaixo das lajes do pavimento, na direção da canalização maior, no entanto a ligação foi destruída pelas ocupações posteriores (Lopes, 2018a, pp. 34-41).

No que concerne a circulação da água neste tipo de espaços, são conhecidas duas modalidades: batistérios com orifícios de entrada e de escoamento, como ocorre no batistério I de Mértola e em Aix, Nantes II, Lyon e Port-bail; e batistérios com apenas um orifício de esvaziamento, como neste batistério II e em Fréjus, Rescamone e Figari (Guyon, 1991, p. 82). Já tem sido abordada a incongruência que se verifica entre o princípio do batismo por imersão e as medidas das piscinas batismais (com diâmetros entre os $1,30 \mathrm{~m}$ e os $1,60 \mathrm{~m}$ e a profundidade a rondar $1 \mathrm{~m}$ ) o que não invalida a sua função. Parece provável que a imersão fosse apenas simbólica e que o celebrante, ou os que o assistiam, lançassem água sobre o que estava a ser batizado. Em todo o caso, o catecúmeno poder-se-ia ajoelhar ou acocorar dentro da piscina, até que a água o cobrisse (Godoy Fernández, 1989, p. 607-635). No entender desta autora não se podem extrair conclusões litúrgicas da profundidade

8. Neste caso o tanque tinha uma largura exterior máxima de 4,80 metros, sendo a largura média exterior nas restantes paredes de 4,63 metros $\mathrm{O}$ interior apresenta uma largura média de 3,25 metros, a profundidade máxima é de 1,52 metros e a profundidade até ao orifício do desaguo é de 1,16 metros. das piscinas pois, caso ela não permitisse a imersão completa, praticava-se uma fórmula mista de "infusión-inmersión" que em nada afetaria a validade da cerimónia (Godoy Fernández, 1989, p. 613). A água sempre teve um papel importante no ato batismal. As primitivas comunidades cristãs manifestavam predileção pela imersão completa do catecúmeno que, nos primeiros tempos, se realizava em fontes de água viva (rio ou mar), imitando o Batismo de Jesus Cristo no Rio Jordão. Segundo se depreende das palavras utilizadas pelos autores antigos para designar as fontes batismais, a forma mais frequente de conferir o sacramento era a imersão. Os termos mais empregues no ocidente são: fons, lavacrum, piscina $y$ tinctorium e as referências à ação sacramental: mergere, mergitare, in aquas mittere, intinguere, para designar tanto a imersão total como a parcial (Godoy Fernández, 1989, p. 613).

\section{A TORRE DO RIO}

$\mathrm{Na}$ área ribeirinha as estruturas monumentais inscrevem-se na Antiguidade Tardia e são testemunho da importância que a zona portuária possuía nessa época. De todo o conjunto monumental de muralhas existentes, a chamada Torre do Rio (também conhecida por Torre Couraça) é paradigmática das técnicas construtivas do período tardo-romano. A Torre do Rio foi declarada Monumento Nacional em 1910 sendo, na linguagem popular, o monumento designado por "ponte romana”. Um exemplo desta designação encontra-se no foral outorgado a Mértola em 1254 pelo Mestre da Ordem de Santiago, D. Paio Peres Correia, no qual se pode ler Della ponte a suso quem ahy quizer pescar auenhaseis com o comendador do lugar (Veiga, 1983, pp. 177-178). Esta referência à "ponte" mantem-se na documentação produzida pelas visitações da Ordem de Santiago servindo, por exemplo, para determinar o dízimo a pagar pela pesca no rio (Barros, Boiça e Gabriel, 1996, p. 27). Contudo, esta designação carece de qualquer confirmação arqueológica. Abel Viana, que chegou mesmo a efetuar ali trabalhos arqueológicos, informou Fernando de Almeida, que "não encontrara absolutamente nada nas escavações que para tal fim ali fizera" (Almeida, 1976, p. 265). De facto não se trata de uma ponte, mas de um passadiço constituído por seis pilares e outros tantos arcos (dos quais apenas se conserva a zona do arranque), que se situava entre a Porta da Ribeira e o rio e que permitia ligar o espaço 
intramuros ao Guadiana. A sua extensão total ronda os 47,8 m; no entanto, se considerarmos a ligação, inevitável, à muralha, a dimensão do monumento chega aos 51,3 m (Figura 10).

No nível superior dos pilares é percetível o arranque dos arcos que ligariam todo o conjunto, existindo nos pilares dois, três, quatro e seis arcos menores, hoje parcialmente destruídos, que teriam como função aliviar a pressão exercida sobre a estrutura, deixando passar parte das águas vindas de montante e diminuindo o impacto da força da corrente. Esses sumidouros possuem uma largura regular que se situa em 1,3 m, com exceção do pilar 6 cujo arco apresenta 1,5 m de largura. Esta técnica construtiva é adotada na maior parte das pontes construídas durante o período romano. Numa imagem fotográfica de Mértola do ano 1875, um ano antes da grande cheia, ainda é visível a união, por um arco, entre o terceiro e o quarto pilar (Custódio, 2013, p. 21).

No que se refere à técnica construtiva, esta é claramente idêntica à que foi adotada na edificação do criptopórtico. Temos, assim, um terminus ante quem para a construção do criptopórtico proporcionado pela pavimentação dos espaços com mosaicos, para os quais os paralelos existentes se situam maioritariamente no século VI d C. A Torre do Rio em si insere-se num espectro cronológico entre os finais do século III, data posterior à da ara votiva aqui encontrada, e o século VI, limite cronológico atribuído à aplicação dos pavimentos musivos existentes sobre o criptopórtico do complexo religioso de Mértola. Mais tarde, durante a permanência islâmica, não terá perdido a função de defesa do porto mas também poderia ter tido a funcionalidade de abastecer a vila de água através de uma zona protegida. No desenho de Duarte D’Armas, de 1509/10, é descrita: pegões de poonte começados em tempo de mouros (Almeida, 1943), possivelmente remetendo para a última utilização desta edificação. Estácio da Veiga e Pavón Maldonado coincidem na opinião de que esta mantinha em época islâmica uma função de torre couraça para aprovisionar a água à população (Pavón Maldonado, 1993, p. 38).

\section{ALGUMAS CONCLUSÕES E QUESTÕES EM ABERTO}

As escavações arqueológicas levadas a cabo na Casa Cor-de-Rosa abrem novas perspetivas para a compreensão do urbanismo romano, pondo a descober- to uma estrutura monumental, de caráter público, possivelmente um templo. Estruturas encontradas em 2006 e 2007, no acompanhamento da obra de recuperação da Casa Fagulha, relativamente próxima, parecem situar-se no mesmo alinhamento destas, pelo que poderão constituir, eventualmente, o prolongamento deste edifício até esse outro imóvel. Estas estruturas monumentais estariam, possivelmente, integradas numa praça do tipo forum, constituído por plataformas e coroado por um templo. Com ela se relacionaria a descoberta do século XVI no torreão que deu lugar à Igreja da Misericórdia, de seis ou oito estátuas às quais viriam a juntar-se, no final de 2017, mais quatro exemplares exumados no âmbito dos trabalhos arqueológicos realizados (Lopes, 2018).

Dada a monumentalidade das estruturas e a concentração da estatuária encontrada nesta parte da vila, é perfeitamente admissível que nesta zona existisse um forum que se desenvolveria em plataformas e que possivelmente teria um rico programa iconográfico estatuário de forte impacto visual. Quem chegava a Myrtilis, subindo o rio Guadiana, deparava-se com um cenário monumental constituído por imponentes templos ricamente ornamentados.

A concentração de estruturas e achados escultóricos e de elementos de arquitetura decorativa de grandes dimensões na parte baixa da vila de Mértola vem reacender o debate em torno da topografia antiga de Myrtilis e colocar a possibilidade da existência de dois fora, um na parte alta da cidade e, um outro, na parte baixa ligado aos prováveis templos de Augusto e de Cibele possivelmente localizados nas imediações da zona portuária (Figura 10).

Se excetuarmos o togado que se encontra no Museu Nacional de Arqueologia, que apresenta a parte de trás lisa, para encostar a uma parede, todos os outros elementos escultóricos estão trabalhados em todos os lados, deveriam ser vistos em todos os seus ângulos.

Os elementos escultóricos encontrados em Mértola demonstram a prática da Damnatio memoriae, bem visível nas cabeças e em concreto nas faces, com a destruição dos queixos e dos narizes. Esta prática está também documentada no caso das estátuas ocultadas na vala. A Damnatio memoriae das peças escultóricas, ou seja, a destruição parcial e a ocultação propositada, num contexto arqueológico bem datado, atesta um processo de cristianização em que uma religião politeísta foi substituída por uma religião monoteísta - o cristianismo. Terá sido um mo- 
vimento semelhante, conduzido pelos cristãos vitoriosos após 312, que levou à mutilação, destruição e enterramento das estátuas da Antiguidade romana. Se ela foi objeto de um motim de fúria popular como esses, mais ou menos espontâneo, ou se de um ritual oficial de dessacralização ('maledictio' ou 'damnatio') oficial. Temos assim documentado arqueologicamente um episódio de conflito e da intolerância entre religiões nos inícios da Antiguidade Tardia, e de como os acontecimentos religiosos marcaram o tecido urbano da antiga cidade de Mértola.

Estas novas descobertas reafirmam a importância histórica desta cidade portuária e o seu forte grau de romanização. No período subsequente Mértola mantem a dinâmica e a importância que se materializam no Complexo religioso, nas basílicas do Rossio do Carmo e do Cineteatro Marques Duque e no mausoléu (Lopes, 2019).

Mértola, julho de 2020

\section{BIBLIOGRAFIA}

ALMEIDA, Fernando (1976) - A ruínas da Chamada Ponte Romana de Mértola (Portugal). In Madrider Mitteilungen, 17, pp. 295-300.

ALMEIDA, JOÃO de (1943) - Livro das Fortalezas de Duarte De Armas, Lisboa.

BARROS, Maria, BOIÇA, Joaquim \& GABRIEL, Celeste (1996) - As comendas de Mértola e Alcaria Ruiva - As Visitações e os Tombos da Ordem de Santiago 1482-1607, Mértola.

BOIÇA Joaquim e BARROS Maria de Fátima R. (2013) - O castelo de Mértola, Mértola.

BOIÇA, Joaquim (1993) - Topografia Histórica de Mértola. Arqueologia Medieval, 3, pp. 47-59.

BARROS, Maria, BOIÇA, Joaquim \& GABRIEL, Celeste (1996) - As comendas de Mértola e Alcaria Ruiva - As Visitações e os Tombos da Ordem de Santiago 1482-1607, Mértola.

BOURGUET, Pierre (1965) - La peinture paléo-chrétienne, Port Royal, 3, Suiça.

BRANCO, Manuel da S. C. (1997) - Duarte de Armas Livro das Fortalezas, Edição fac-similado MS 159 da Casa Forte do Arquivo Nacional da Torre do Tombo ( $2^{\mathrm{a}}$ ed.). Lisboa.

COSTA, Miguel R. (2015): - Mértola A arquitetura da vila e do termo, Mértola.

CUSTÓDIO, Jorge (2013) - Mina de S. Domingos, território, história e património mineiro. Lisboa: Socius - ISEG, Universidade de Lisboa.
DIAS, M. M. Alves, GASPAR, Catarina (2006) - Catálogo das Inscrições Paleocristãs do Território Português, Centro de Estudos Clássicos, Universidade de Lisboa.

DIAS, M. M. Alves, GASPAR, Catarina e LOPES, Virgílio, (2013) - Mértola en la Antigüedad Tardía: Nuevos datos arqueológicos y epigráficos. HABIS, 44, 247-267.

GARCIA y BELLIDO, (1966-67) - Retratos Romanos Imperiales de Portugal, Arquivo de Beja, Volume XXIII-XXIV, Beja, pp. 280-291.

GODOY FERNÁNDEZ, Cristina (1989) - Baptistérios hispánicos (siglos IV aI VIII): arqueología y liturgia. In Actes du XI Congrès international d'archéologie chrétienne vol. 1, Rome, pp. 607-635.

GUYON Jean, (1991) - Le baptême et ses monuments. In Naissance des arts chrétiens: atlas des monuments paléochrétiens de la France, Paris, pp. 70-87.

LOPES, Virgílio (2003) - Mértola na Antiguidade Tardia. Mértola.

LOPES, Virgílio (2012) - Casa romana: Museu de Mértola. Mértola.

LOPES, Virgílio (2014) - Mértola e o seu território na antiguidade tardia (séculos IV-VIII). Huelva: Universidade de Huelva. Dissertação de Doutoramento, 2014. Disponível em http://rabida.uhu.es/dspace/ handle/10272/8053

LOPES, Virgílio, (2018a) - O complexo religioso de Mértola. Monumentos, nº 36, Direção Geral do Património Cultural, Lisboa, pp. 54-61.

LOPES, Virgílio, (2018b) - Recentes descobertas arqueológicas em Mértola: a intervenção na Casa Cor-de-Rosa, Monumentos, no 36, Direção Geral do Património Cultural, Lisboa, ISBN 0872-8747, pp. 34-41.

LOPES, Virgílio, (2019) - Mértola e o seu território na Antiguidade Tardia. In Tarraco bienal ACTES 4 t Congrés Internacional d'Arqueologia i Món Antic VII Reunió d'Arqueologia Cristiana Hispànica El cristianisme en l'Antiguitat Tardana Noves perspectives, Tarragona, 21-24 de novembre de 2018, Edició a cura de Jordi López Vilar, Tarragona, 2019, pp. 377-384.

MACIAS, Santiago (1993) - Um espaço funerário. In Museu de Mértola: basílica paleocristã, Mértola, pp. 30-62.

MACIAS, Santiago (1996) - Mértola islâmica: estudo histórico do Bairro da Alcáçova (séculos XII-XIII), Mértola.

NICOLAI, Vincenzo. F., BISCONTI, Fabrizio. \& MAZZOLENI, Danilo, (200o) - Les catacombes chrétiennes de Rome. Turnhout: Brepols Publishers.

TORRES, Cláudio e OLIVEIRA, José C. (1987) - O criptopórtico-cisterna da Alcáçova de Mértola. In II Congreso de Arqueología Medieval Española, Madrid, 1987. (T. II, pp. 617-626). Madrid: [Comunidad de Madrid]. 
TORRES, Cláudio e SILVA, Luís, (1989) - Mértola Vila Museu, Mértola.

TORRES, Cláudio (1992) - Povoamento antigo no Baixo Alentejo: alguns problemas de topografia histórica. Arqueologia Medieval, n. 1, pp. 197-198.
VEIGA, Estácio da (1983) - Memórias das Antiguidades de Mértola, (ed. fac-similada de 1880). Lisboa: Imprensa Nacional, Mértola.

PAVÓN MALDONADO, B. (1993) - Ciudades y fortalezas lusomusulmanas: crónicas de viajes por el sur de Portugal. Madrid: Instituto de Cooperación con el Mundo Arabe.

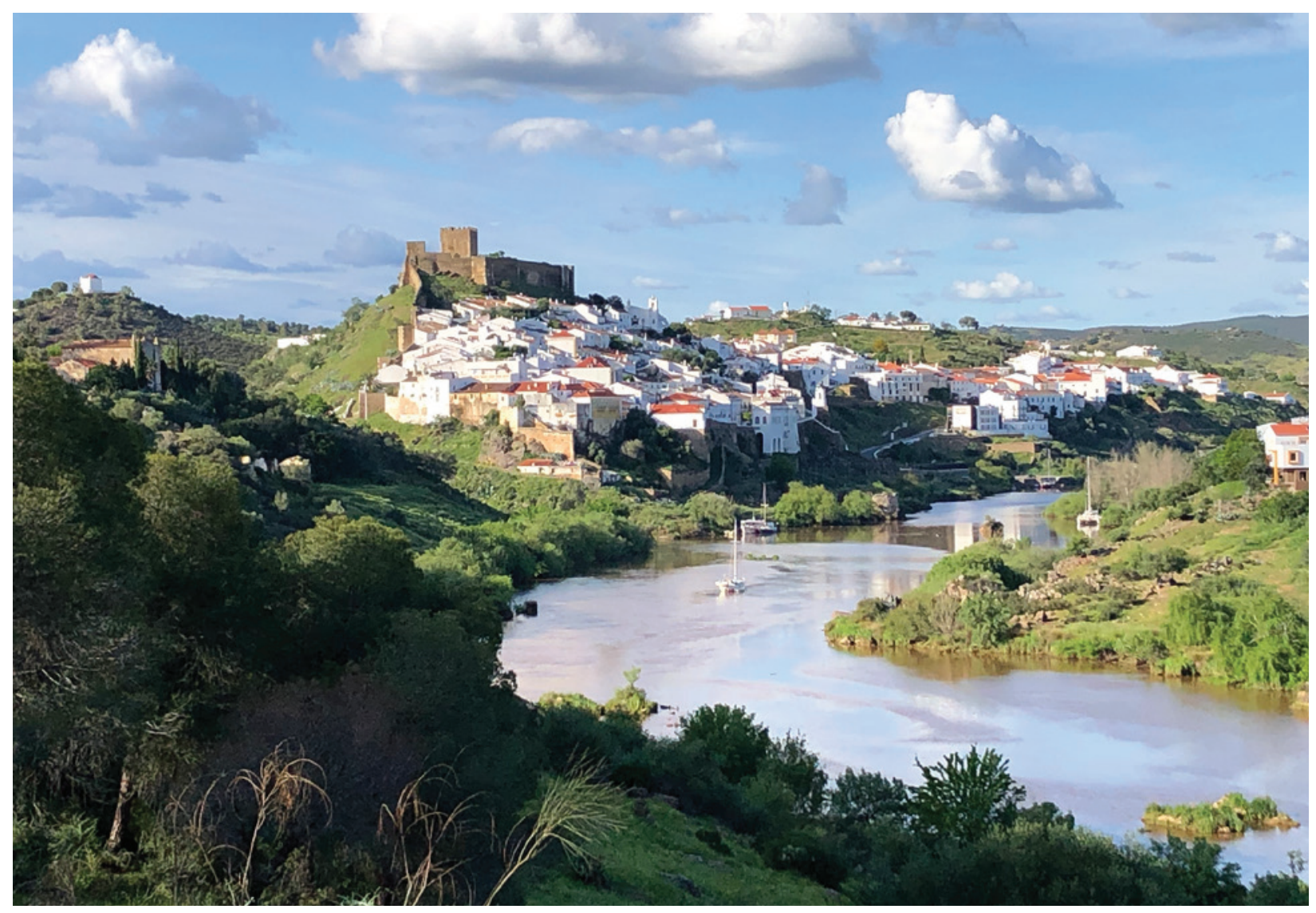

Figura 1 - O rio Guadiana e Mértola.

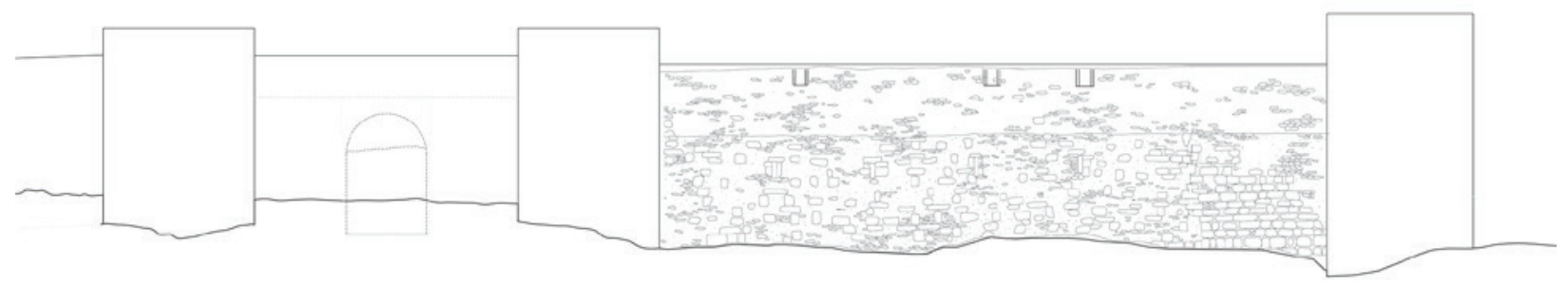

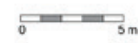

Figura 2 - A muralha exterior do criptopórtico e a porta (desenho Carlos Alves). 


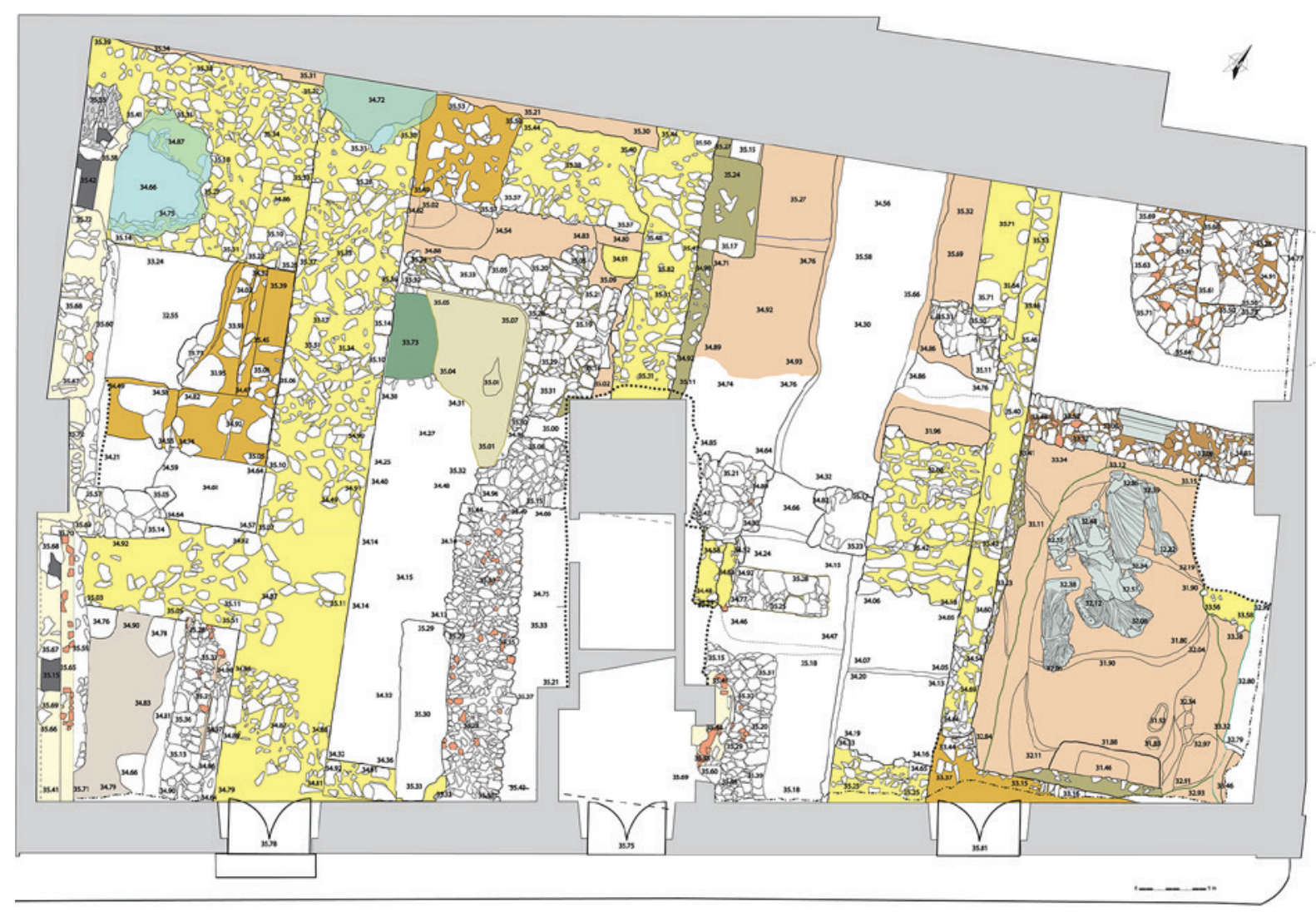

Figura 3 - Planta Casa cor de Rosa (desenho Nélia Romba e Marco Fernandes).

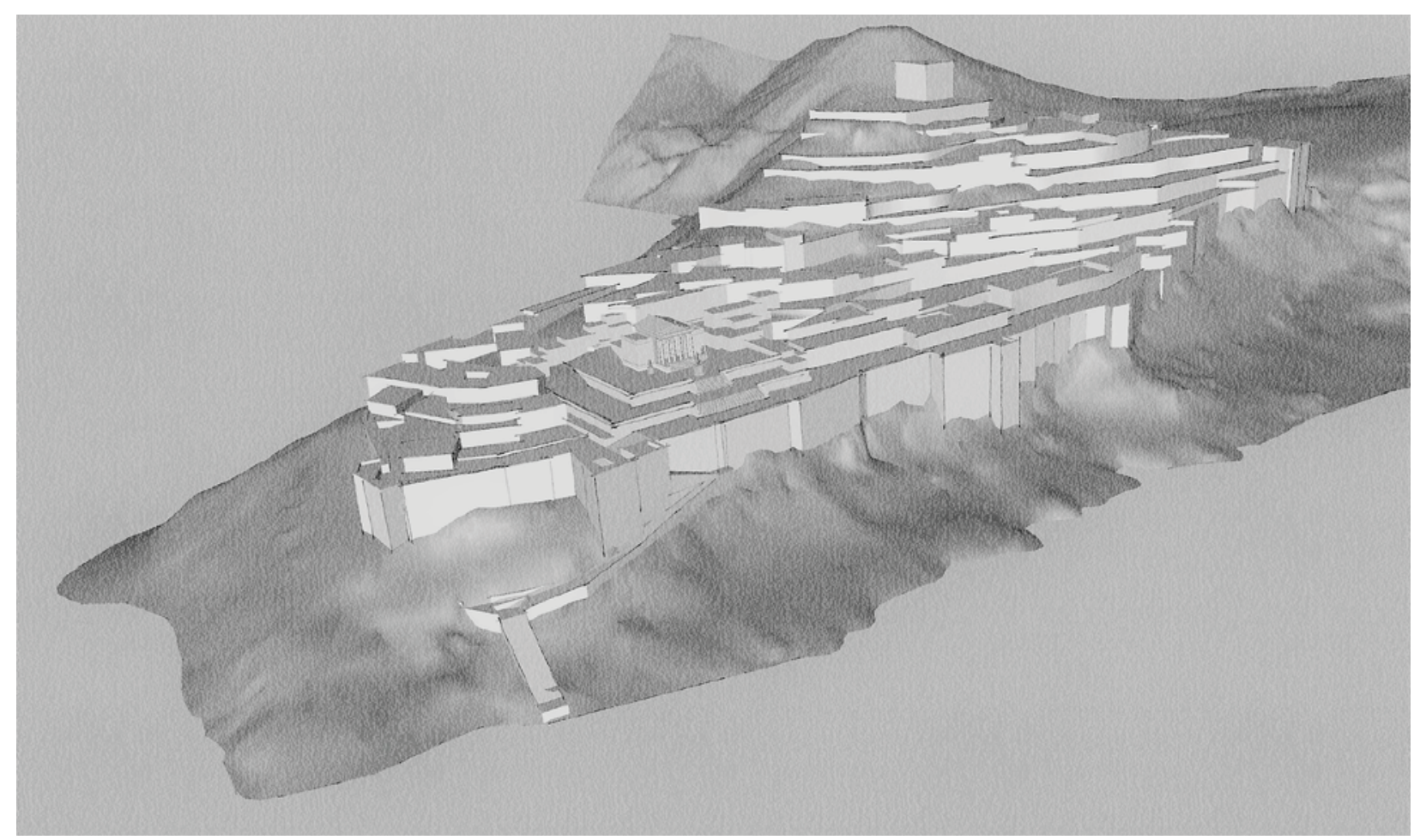

Figura 3 - Proposta de reconstituição volumétrica da parte baixa de Myrtilis (desenho Carlos Alves). 


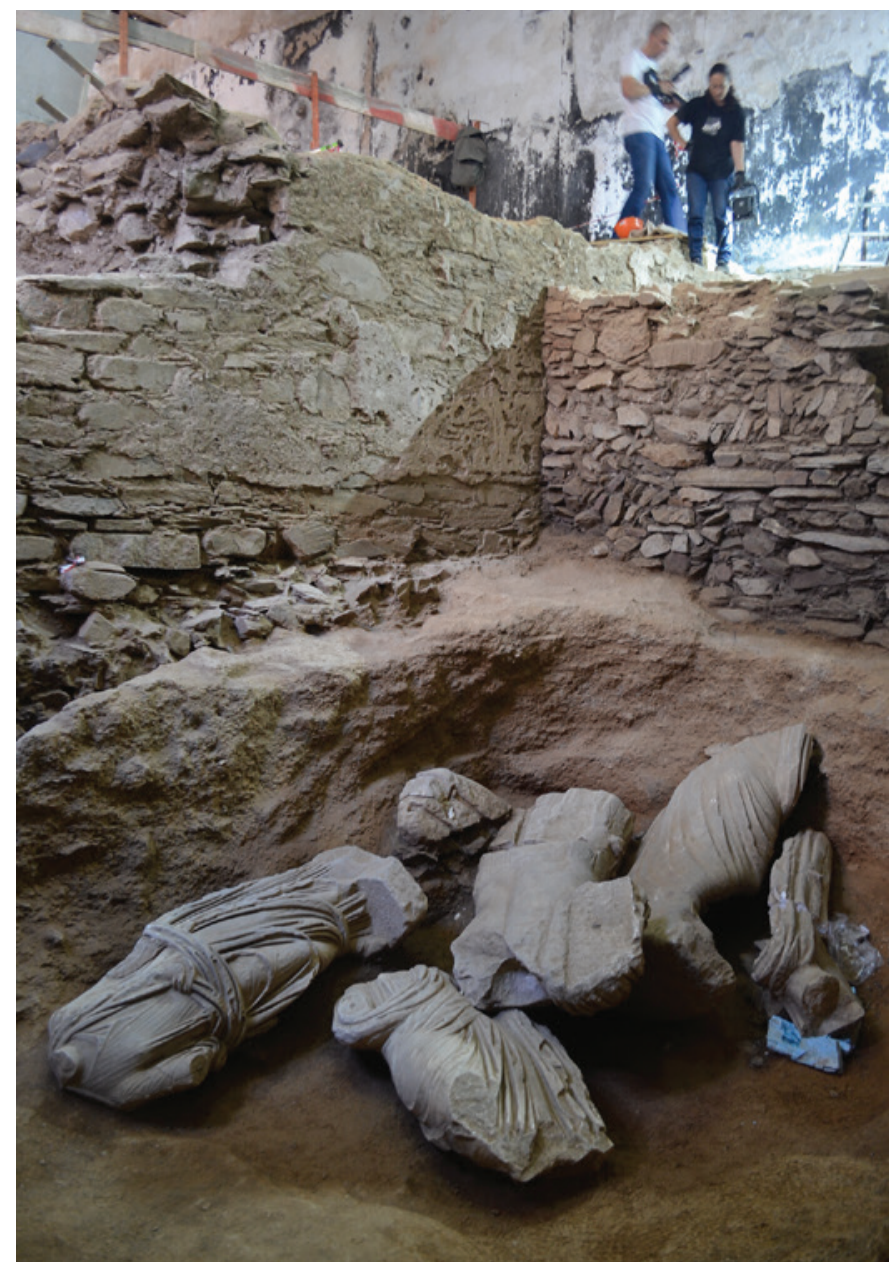

Figura 5 - Escavação do grupo escultórico na Casa Cor de Rosa.
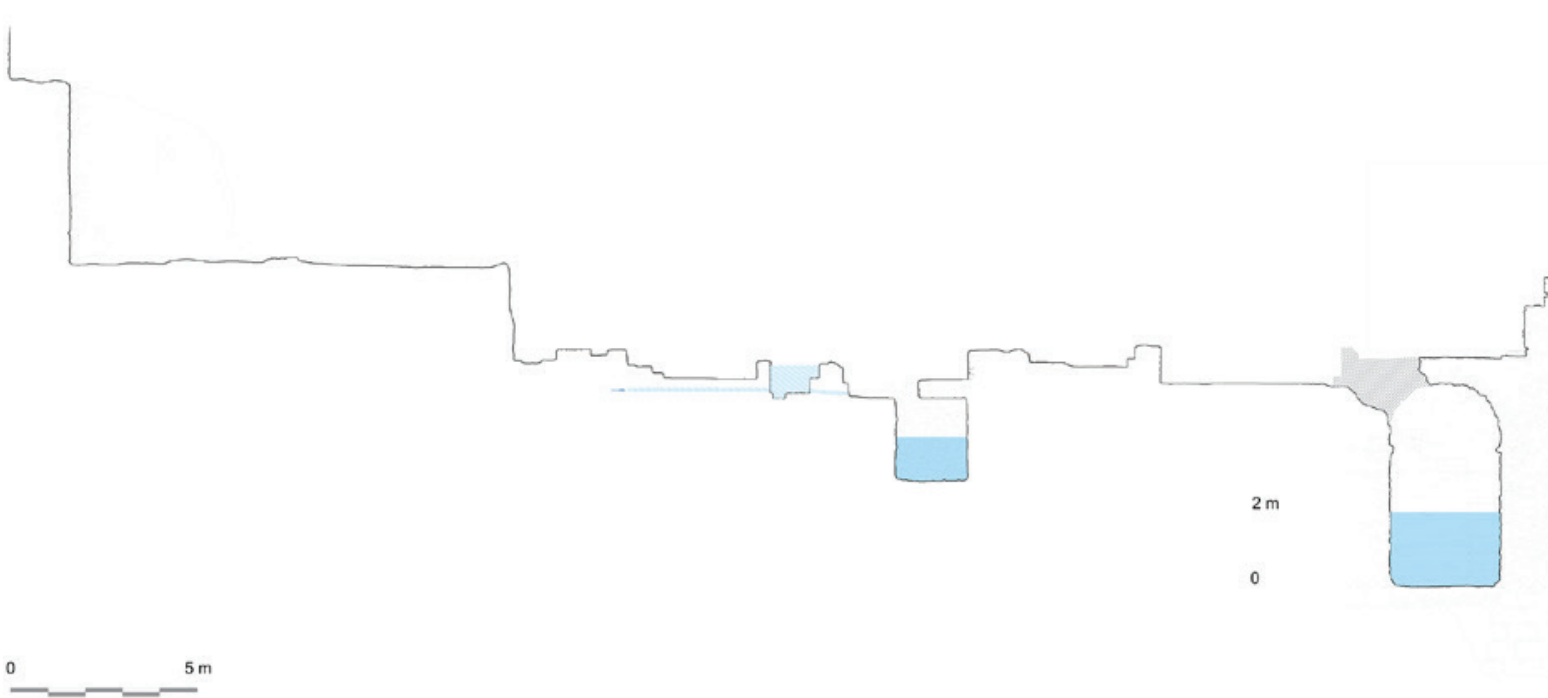
m

Figura 6 - Corte da zona batismal e do criptopórtico (desenho Carlos Alves). 


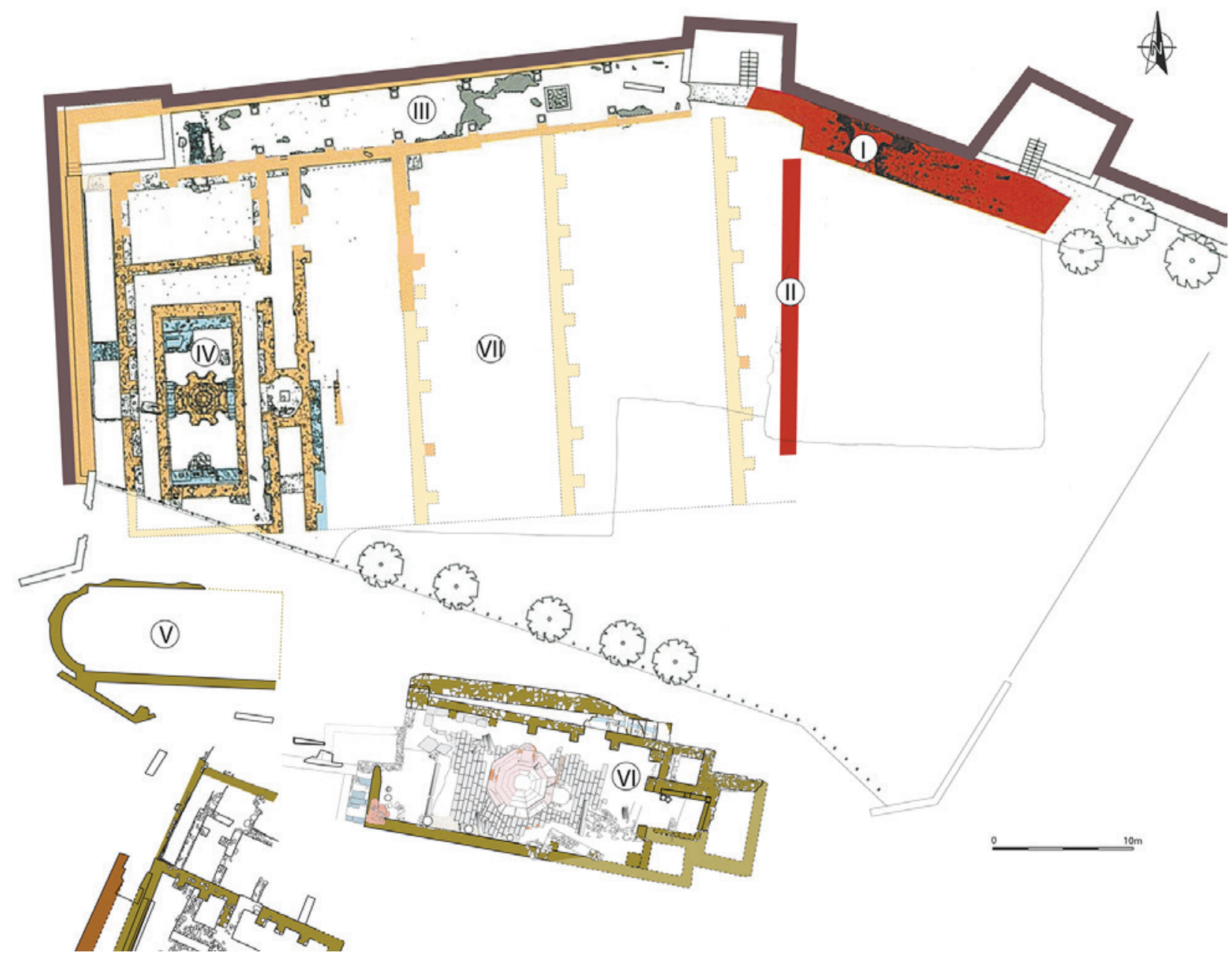

Figura 7 - Planta geral do complexo religioso. Planta do complexo religioso: I - Porta do forum, II Arcossólios, III Pórtico, IV Batistério I, V Compartimento absidado, VI Batistério II (desenho de Nélia Romba). 


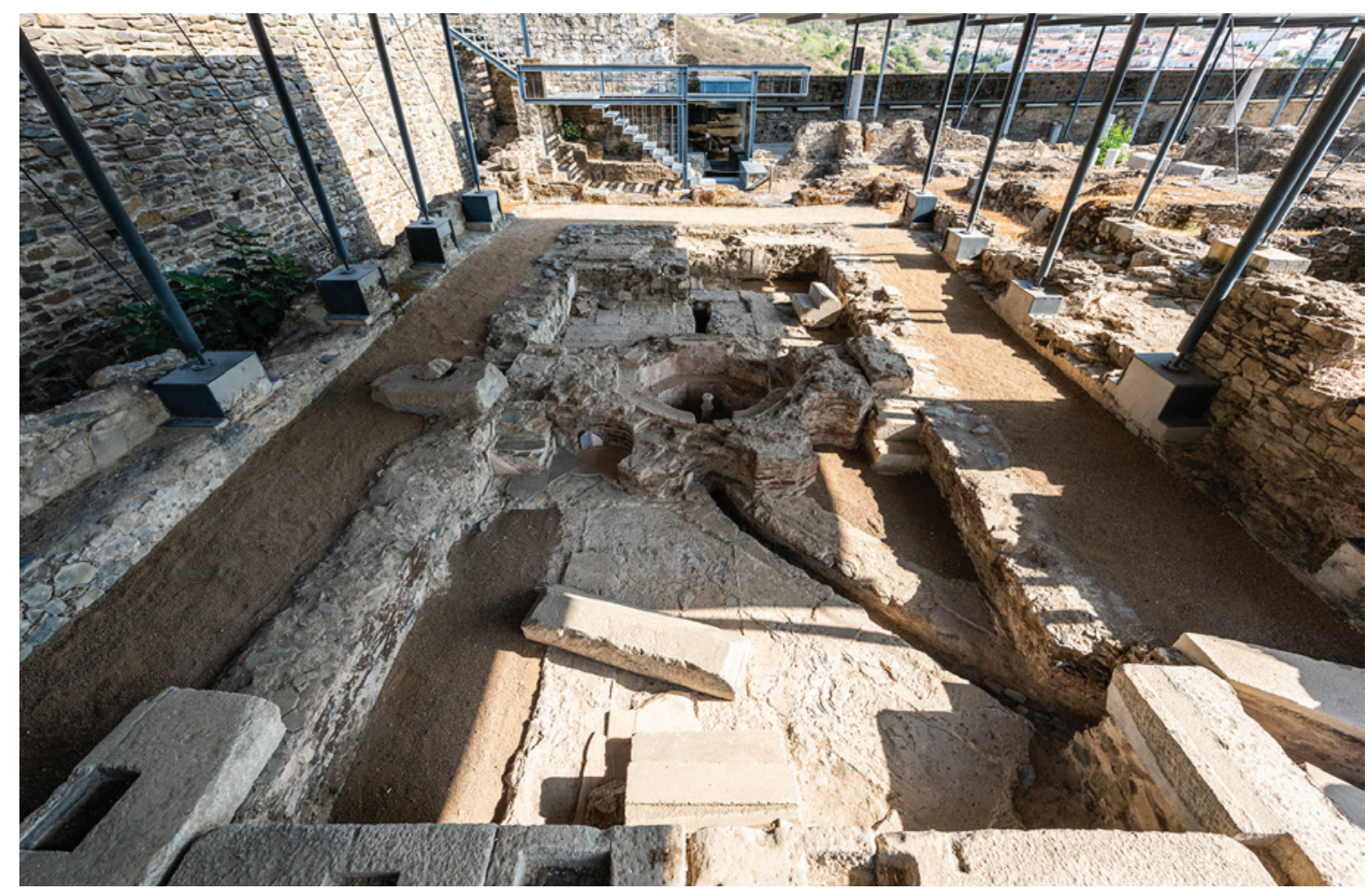

Figura 8 - Batistério I (Jorge Branco CMMértola).

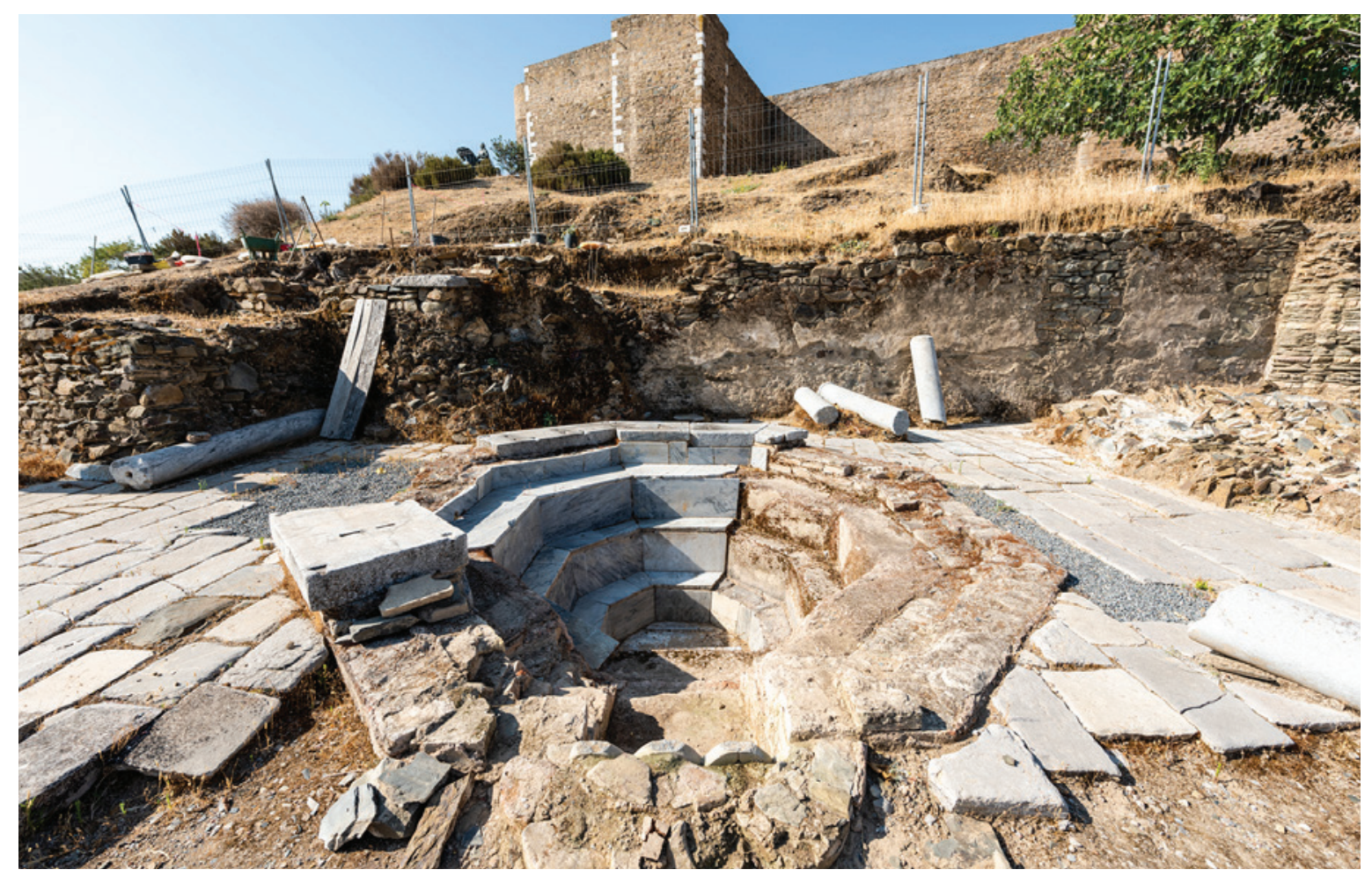

Figura 9 - Batistério II (Jorge Branco CMMértola). 

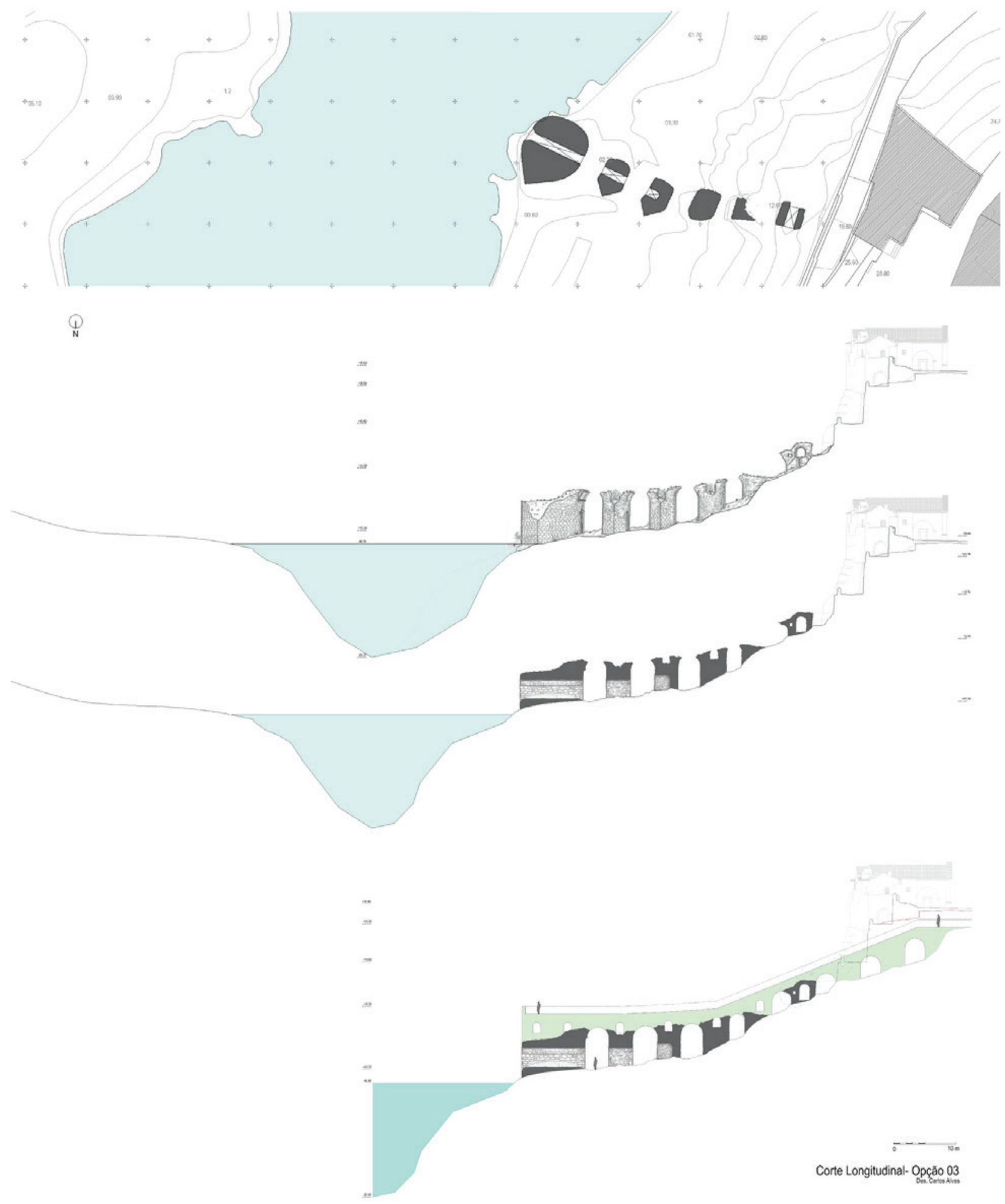

Figura 1o - Torre do Rio (desenho Carlos Alves). 


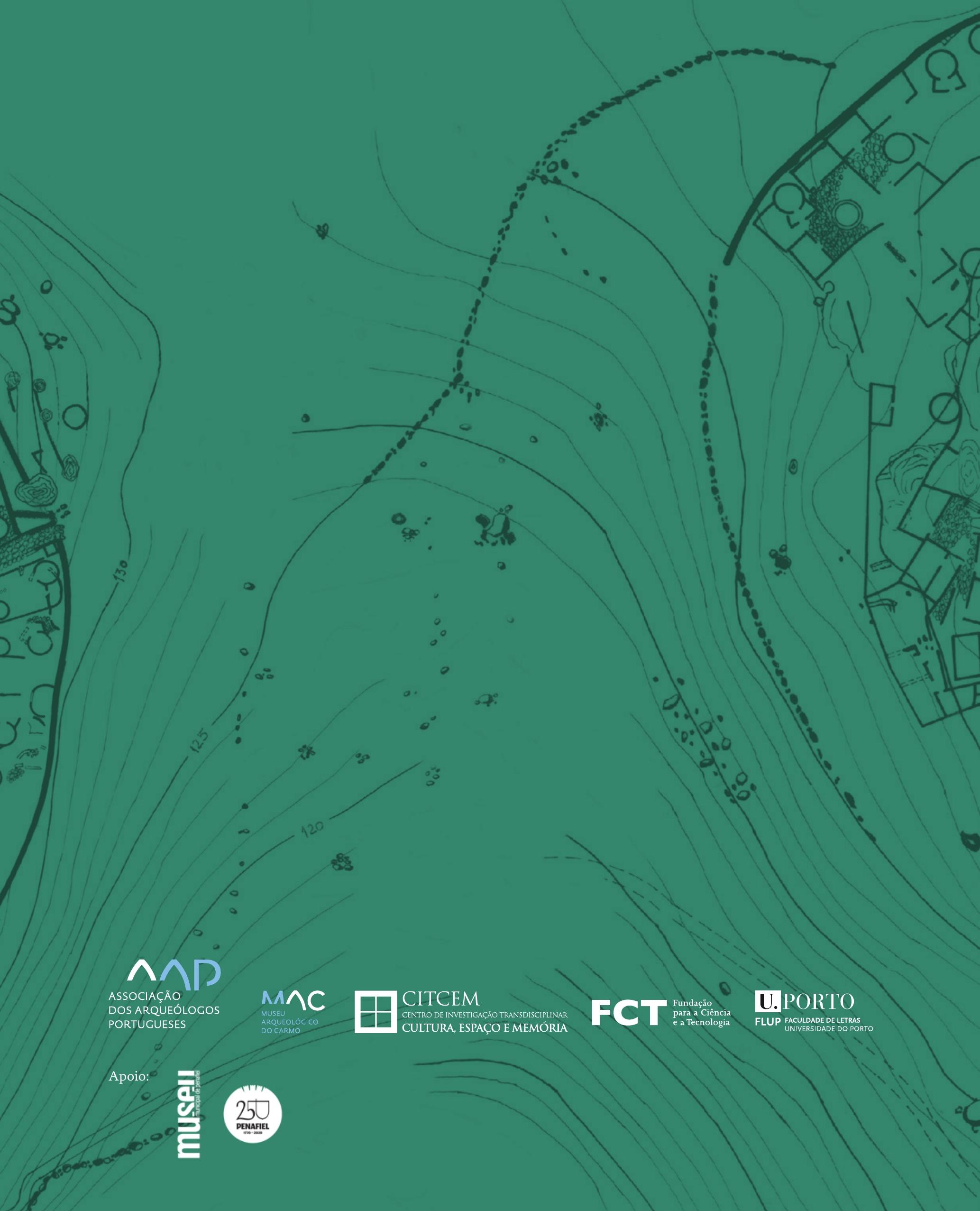

